\title{
BIO-ECONOMIC PERFORMANCE OF ORGANIC CUCUMBER (CUCUMIS SATIVUS L.) UNDER WOODLOTS-BASED AGROFORESTRY SYSTEMS
}

\author{
AMIN, M. H. A. ${ }^{1,2}$ - BEGUM, M. L. ${ }^{1}-$ AKTER, M. M. ${ }^{3}$ - PARVEJ, M. M. R. ${ }^{4}-$ \\ JUTIDAMRONGPHAN, W. ${ }^{5,6}-$ TECHATO, K..$^{5,6^{*}}$ \\ ${ }^{1}$ Agroforestry and Environment, Faculty of Agriculture, Hajee Mohammad Danesh Science and \\ Technology University, Dinajpur-5200, Bangladesh \\ ${ }^{2}$ Sustainable Energy Management, Faculty of Environmental Management, Prince of Songkla \\ University, Hat Yai, 90110 Songkhla, Thailand \\ ${ }^{3}$ Agriculture Innovation and Management Division, Faculty of Natural Resources, Prince of \\ Songkla University, Hat Yai, 90110 Songkhla, Thailand \\ ${ }^{4}$ Officer (Chemicals), Padma Oil Company Limited, Bangladesh \\ ${ }^{5}$ Environmental Assessment and Technology for Hazardous Waste Management Research \\ Center, Faculty of Environmental Management, Prince of Songkla University, Hat Yai, 90110 \\ Songkhla, Thailand \\ ${ }^{6}$ Center of Excellence on Hazardous Substance Management (HSM), Bangkok 10330, Thailand \\ ${ }^{*}$ Corresponding author \\ e-mail: kuaanan.t@psu.ac.th; phone: +66-74-286803; fax:+66-74-429-758 \\ (Received $6^{\text {th }}$ Apr 2021; accepted $8^{\text {th }}$ Jul 2021)
}

\begin{abstract}
The demand for cucumber has risen globally due to its nutraceutical properties and positive health effects. Recently, cucumber has been grown as an associate crop to maximize land-use efficiency. Therefore, this research aimed to find the maximum cucumber yield and economic feasibility under Albizia lebbeck, Melia azedarach, and Leucaena leucocephala woodlots-based agroforestry with mulching. The results revealed that the highest cucumber fruit yield ( 9.15 tons/ha) was attained by growing under Albizia lebbeck with dry water hyacinth mulch. Similarly, the benefit-cost ratio (BCR) was the highest (2.89) cucumber Albizia lebbeck woodlot agroforestry, twice as much as mono-cropping production. Thus, it would be concluded that cucumber grown under Albizia lebbeck woodlot agroforestry with dry water hyacinth mulch can be a cost-effective production practice for securing higher yields.

Keywords: mulching, multi-production approach, yield potentiality, benefit-cost ratio, trellis vegetable
\end{abstract}

\section{Introduction}

The Cucumber (Cucumis sativus L.) is an annual trailing vine vegetable belonging to the Cucurbitaceae family. This vegetable is highly offered in the low-fat diet due to its minimum cholesterol content, saturated fat and calories with a higher amount of vitaminA, vitamin-C, vitamin-K and potassium (Mukherjee et al., 2013). These green fruits produce $(0.6 \mathrm{~g})$ protein, $(2.6 \mathrm{~g})$ fibre $(12$ calories $)$ energy, $(18 \mathrm{mg}) \mathrm{Ca},(0.2 \mathrm{mg}) \mathrm{Fe},(0.02$ $\mathrm{mg})$ thiamin, $(0.02 \mathrm{mg})$ riboflavin, $(0.01 \mathrm{mg})$ niacin, and $(10 \mathrm{mg})$ vitamin $\mathrm{C}$ per $100 \mathrm{~g}$ (Rashid, 1999). Additionally, this trellis vegetable frequently produces a higher amount of phytochemicals such as alkaloids, flavonoids, steroids, and tannins commonly used in the cosmetic and pharmaceutical industries (Rajasree et al., 2016). The daily intake of plant-based foods has been well demonstrated to fulfil an essential part in reducing 
chronic and degenerative diseases (Hu, 2003; Trichopoulou et al., 2014). However, in recent years, in Bangladesh, people have been intake vegetables $112 \mathrm{~g} /$ day/capita ( $23 \mathrm{~g}$ green vegetables, $89 \mathrm{~g}$ non-leafy plants), less than the lowest demand of $400 \mathrm{~g} /$ day/capita (WHO, 2003). The crop is grown in Bangladesh around 9,593 ha of land and the production 65,499 metric tons, with an average yield of 6.83 tha $^{-1}$ (Anonymous, 2018). This production potential is very poor compare to other cucumber growing countries (Hossain et al., 2018), and their average yield is more than 30 tha $^{-1}$. Therefore, a significant gap between vegetable demand and supply has been identified to be a critical problem.

The conventional land-use schemes would become more fragile due to enhanced ambient temperature, amounts of $\mathrm{CO}_{2}$, and other greenhouse gases. The consequence reduced the productive capacity of the system (FAO, 2013). Moreover, the depletion and destruction of forests worsen food insecurity both explicitly and indirectly: directly, by influencing the availability of fruits and timber- and tree-based food items, and indirectly by changing ecological factors important for crop and livestock. (Van Noordwijk et al., 2014). In the last three decades, agroforestry has been actively advocated in tropical and sub-tropical countries as a natural resource conservation technique (Izac and Sanchez, 2001). These multi-production strategies are becoming very popular nowadays due to the diversified production approach (Garrit, 2004). Significant advantages of adopting the strategies are - increased soil fertility, water availability, minimized soil degradation and improved bio-diversity (Chakraborty et al., 2015).

Agroforestry can be attributed to being a multi-functional system that can be ecologically and economically sensitive and addresses socio-economic needs (Sharmin and Rabbi, 2016). The benefits are manifold - compensated losses due to destructions on agriculture and forestry property by natural calamities, enhanced daily-life benefits, tackled rural socio-economic demands, mitigated the problem of climate change and so on (Amin et al., 2017a; Reppin et al., 2020). The harvested products from agroforestry practices (human food, cattle fodder, timber, gum, and construction materials) assist the basic needs (Rahman et al., 2012). Poverty is further alleviated by increasing incomes and involving women in development activities (Rahman et al., 2017).

Multipurpose tree plantations alone or paired with crops may be a successful land rehabilitation method (Maikhuri et al., 2000). The fast-growing small crowns of deciduous nitrogen-fixing trees are the critical factors for sustainable and effective agroforestry practices. In agroforestry practice (Albizia Lebbeck L.), the woody perennial contributes to economic aspects (Amin et al., 2017b). As an alternative, (Leucaena leucocephala Lam.) is frequently grown in tropical and sub-tropical countries that offer a vast timber, fodder, and healthy food source. The leaves, seeds and fruits extracts of (Melia azedarach L.) have been shown a wide choice of therapeutic and pesticide actions against different pathogenic and pest species. These also have anti-inflammatory activity, analgesic, antimalarial activity (Vishnukanta and Rana, 2010), and anticancer (Ntalli et al., 2010).

Teame et al. (2017) stated that organic mulching had a substantial influence on soil moisture content that contributes to the sound development of crops compared to no mulching. Farming with organic mulching eradicated the growth of weed vegetation, lesser crop evaporation rate and created a channel for rainwater infiltration (Yang et al., 2003). Sinkevičienè et al. (2009) reported that organic mulches have plentiful advantages for crop farming by improving the soil chemical, physical, and biological conditions. Sønsteby et al. (2004) found significant potassium and phosphorus percentages in crop 
leaves due to the used sawdust. The organic straw mulch also served as a great source of micronutrients in the soil (Sønsteby et al., 2004). Organic grass mulch had the same potentiality (Cadavid et al., 1998). The application of organic mulching on crop production improved plant development, fruit settings and quality yield (Singh et al., 2007; Sharma et al., 2008). Organic material mulching had given some advantages to the root growth, fruit yield, and total soluble solids content (Olfati et al., 2008). Microbial behaviour, which depends on organic material supply, performs a vital role in controlling soil fertility and the transfer of organic matter (Marinari et al., 2007). Soil microorganisms interact quickly to enable the soil to break dormancy and increase mass and spread if conditions are suitable (Xu et al., 2006).

Moreover, in the world food scenario, the food protection concept has to be addressed in technological advancement regarding agricultural research. Direct physical and affordable access to sufficient balanced food satisfying the daily nutritional requirements and food preferences complimenting the wellbeing for everybody at every time can be termed as food protection (World Food Summit, 1996).

The authors have an intriguing interest in addressing the issues mentioned above in this study. In the most petite case, finding out the cheapest environmental-friendly way of enhanced cucumber production pertaining to social, economic, and ecological aspects. The field research aims to select a suitable cucumber production technique considering the growth, yield, and economic potency.

\section{Materials and methods}

\section{Research site with soil and climate}

The study area was situated in the northern part of Bangladesh under the Agroforestry and Environment Department of Hajee Mohammad Danesh Science and Technology University, Dinajpur. The height of the experimental site was 37.5 metre from the mean sea level (MSL). The research field was followed the old Himalayan Piedmont Plain Area (AEZ No. 01), indicating medium-high land with no water logging condition (Brammer et al., 1988). The soil physical and chemical properties of the experimental field are presented in Table 1 . The average air temperature $\left({ }^{\circ} \mathrm{C}\right)$, relative humidity $(\%)$, rainfall $(\mathrm{mm})$, and sunshine (hrs) of the experimental site are presented in Fig. 1 from April to July 2020. The maximum air temperature $\left(31.5^{\circ} \mathrm{C}\right)$ was recorded in May, and the minimum air temperature $\left(19.90^{\circ} \mathrm{C}\right)$ was noted in April. The relative humidity was found a minimum fluctuation from $83.00 \%$ to $92.00 \%$. Instead, the highest monthly precipitation $(92.0 \mathrm{~mm})$ was found in July, and the lowest $(31.0 \mathrm{~mm})$ was observed in April. In the sunshine, the monthly average variation range from $220.12 \mathrm{hrs}$ to $280.4 \mathrm{hrs}$.

\section{Plant materials}

The woodlots of sixteen (16) years old Albizia lebbeck, Melia azedarach, and Leucaena leucocephala were the experimental fields for the present research work. The trees were arranged in east-west geometry with a 3 metres plant to plant and 3 metres for a row to row difference. At the time of experimentation, the woodlots tree characteristics were showed in Table 2. Among the 3 (three) tree species, the mean $(\mathrm{n}=12)$ the plant height, clean bole height, base girth, bole girth, and diameter at breast height $(15.0 \mathrm{~m}$, $7.5 \mathrm{~m}, 118.0 \mathrm{~cm}, 97 \mathrm{~cm}$, and $31 \mathrm{~cm}$ ) was recorded from Albizia lebbeck woodlot. On the other hand, the Melia azedarach woodlot had $(17.5 \mathrm{~m})$ plant height, $(10.5 \mathrm{~m})$ clean bole 
height, $(125.0 \mathrm{~cm})$ base girth, $(95.0 \mathrm{~cm})$ bole girth, and $(30.3 \mathrm{~cm})$ diameter at breast height. Moreover, the average plant height, clean bole height, base girth, bole girth, and diameter at breast height $(21.5 \mathrm{~m}, 15.5 \mathrm{~m}, 88 \mathrm{~cm}, 82 \mathrm{~cm}$, and $26.0 \mathrm{~cm})$ were observed Leucaena leucocephala woodlot, respectively. The modern Hybrid Green Bird cucumber variety was the research testing crop (Table 2).

Table 1. The soil physical and chemical properties of the experimental field

\begin{tabular}{c|c}
\hline Soil characters & Physical and chemical properties \\
\hline Sand $(\%)$ & 63 \\
Silt $(\%)$ & 32 \\
Clay $(\%)$ & 5 \\
Textural class & Sandy loam \\
CEC (meq/ 100g) & 8.2 \\
$\mathrm{p}^{\mathrm{H}}$ & 5.2 \\
Organic matter $(\%)$ & 1.28 \\
Total nitrogen $(\%)$ & 0.11 \\
Potassium $(\mathrm{meq} / 100 \mathrm{~g})$ & 0.26 \\
Phosphorus $(\mu \mathrm{g} / \mathrm{g})$ & 25.0 \\
Magnesium $(\mathrm{meq} / 100 \mathrm{~g})$ & 0.42 \\
Sodium $(\mathrm{meq} / 100 \mathrm{~g})$ & 0.05 \\
Calcium $(\mathrm{meq} / 100 \mathrm{~g})$ & 1.32 \\
Sulphur $(\mu \mathrm{g} / \mathrm{g})$ & 3.2 \\
Boron $(\mu \mathrm{g} / \mathrm{g})$ & 0.27 \\
Iron $(\mu \mathrm{g} / \mathrm{g})$ & 5.32 \\
Zinc $(\mu \mathrm{g} / \mathrm{g})$ & 0.92 \\
\hline
\end{tabular}

Source: Soil Resources Development Institute, Dinajpur, Bangladesh (2020)

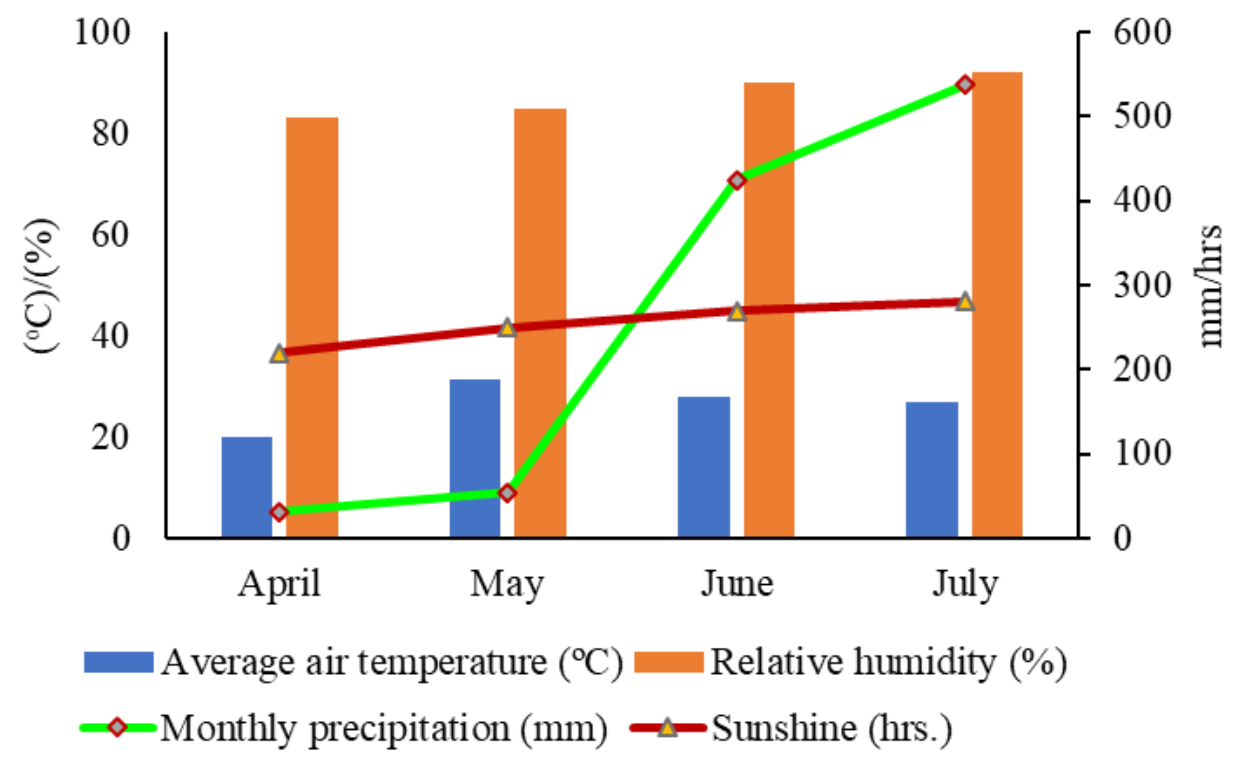

Figure 1. The experimental site weather data during the period from April to July 2020. Source: Meteorological Station, Wheat Research Center, Noshipur, Dinajpur, Bangladesh 
Table 2. The status (mean value) of the woodlot tree species in the research field during the study period $(n=12)$

\begin{tabular}{c|c|c|c|c|c}
\hline $\begin{array}{c}\text { Woodlots } \\
\text { species }\end{array}$ & Plant height $(\mathbf{m})$ & $\begin{array}{c}\text { Clean bole } \\
\text { height }(\mathbf{m})\end{array}$ & $\begin{array}{c}\text { Base girth } \\
(\mathbf{c m})\end{array}$ & $\begin{array}{c}\text { Bole girth } \\
(\mathbf{c m})\end{array}$ & $\begin{array}{c}\text { Diameter at } \\
\text { breast height } \\
(\mathbf{c m})\end{array}$ \\
\hline Albiza lebbeck & 15.0 & 7.5 & 118 & 97 & 31.0 \\
$\begin{array}{c}\text { Melia azedarach } \\
\text { Leucaena }\end{array}$ & 17.5 & 10.5 & 125 & 95 & 30.3 \\
leucocephala & 21.5 & 15.5 & 88 & 82 & 26.0 \\
\hline
\end{tabular}

\section{Design of research with treatments}

The research was designed following two factors split plot and replicated (3) three times of the treatments. Factor A, four production practice treatments, were arranged in the main field, while factor B, three treatments of the organic mulches, were placed in the sub-plot. So, there were twelve (12) treatment combinations. The total number of experimental plots was 36 , and all the plots were the same size, $6.25 \mathrm{~m}^{2}$. The treatments were as follows- factor $A$ : four production systems $T_{1}=$ sole cropping of cucumber (control), $\mathrm{T}_{2}=$ cucumber Albizia lebbeck woodlot agroforestry, $\mathrm{T}_{3}=$ cucumber Melia azedarach woodlot agroforestry, $\mathrm{T}_{4}=$ cucumber Leucaena leucocephala woodlot agroforestry, while factor $\mathrm{B}: \mathrm{M}_{1}=$ no mulch, $\mathrm{M}_{2}=$ ash mulch, $\mathrm{M}_{3}=$ dry water hyacinth mulch. So, the twelve treatment combinations were $\left(\mathrm{T}_{1} \mathrm{M}_{1}\right)$ sole cropping cucumber without mulch, $\left(\mathrm{T}_{1} \mathrm{M}_{2}\right)$ sole cropping cucumber with ash mulch, $\left(\mathrm{T}_{1} \mathrm{M}_{3}\right)$ sole cropping cucumber with dry water hyacinth mulch, $\left(\mathrm{T}_{2} \mathrm{M}_{1}\right)$ cucumber Albizia lebbeck woodlot agroforestry without mulch, $\left(\mathrm{T}_{2} \mathrm{M}_{2}\right)$ cucumber Albizia lebbeck woodlot agroforestry with ash mulch, $\left(\mathrm{T}_{2} \mathrm{M}_{3}\right)$ cucumber Albizia lebbeck woodlot agroforestry with dry water hyacinth mulch, $\left(\mathrm{T}_{3} \mathrm{M}_{1}\right)$ cucumber Melia azedarach woodlot agroforestry without mulch, $\left(\mathrm{T}_{3} \mathrm{M}_{2}\right)$ cucumber Melia azedarach woodlot agroforestry with ash mulch, $\left(\mathrm{T}_{3} \mathrm{M}_{3}\right)$ cucumber Melia azedarach woodlot agroforestry with dry water hyacinth mulch, $\left(\mathrm{T}_{4} \mathrm{M}_{1}\right)$ cucumber Leucaena leucocephala woodlot agroforestry without mulch, $\left(\mathrm{T}_{4} \mathrm{M}_{2}\right)$ cucumber Leucaena leucocephala woodlot agroforestry with ash mulch, and $\left(\mathrm{T}_{4} \mathrm{M}_{3}\right)$ cucumber Leucaena leucocephala woodlot agroforestry with dry water hyacinth mulch.

\section{Land preparation and crop establishment}

The soil of the research field was ploughed by a tractor three times to ensure good tillage. A spade was used to plough the edge of the experimental area. Visibly larger clods were pounded into tiny fragments after ploughing the soil, cleaning the debris and other rubbish for the soil to attain a good cropping condition. The experimental concept was followed in the development of the layout, which was then ready for planting. Every subplot had two pits; three (3) cucumber seeds were sown on $14^{\text {th }}$ April 2020 in each pit, apart from $20 \mathrm{~cm}$ seed to seed distance. The distance between the pit to the pit was 1.8 metre, where the girth of the pit was $75 \mathrm{~cm}$, and the depth was $10 \mathrm{~cm}$. The seeds were later coated in fine soil by hand. During the cropping season, necessary intercultural operations were carried out to ensure proper growth and production. Just one stable seedling was held to develop in each position five to six days after germination, and the others were discarded. Seedlings that were dead, wounded, or frail were substituted with fresh vigour seedlings from the stock stored. As cucumber is a climbing vegetable, trellises were prepared with bamboo and rope fibre with a height of $150 \mathrm{~cm}$ all around in 
sub-plots. Weed was present in large quantities in the control treatment. In the plots where weeding was needed, it was done three times. Light irrigation was applied just after sowing the seeds. After 45 days of seed germination, organic mulching materials were applied in the experimental sub-plots with $2.54 \mathrm{~cm}$ thickness. Green fruits were harvested at 4-5 days intervals when they attained edible, started from $18^{\text {th }}$ June and was continued up to $16^{\text {th }}$ July.

\section{Data recording parameters}

For the growth and production of cucumber, the data was collected in the following heads plant height $(\mathrm{cm})$, leaves plant ${ }^{-1}$, leaf length $\&$ breadth $(\mathrm{cm})$, petiole length $(\mathrm{cm})$, stem girth $(\mathrm{cm})$, main stem internode length $(\mathrm{cm})$, lateral shoots plant ${ }^{-1}$, fruits plant ${ }^{-1}$, fruit height $(\mathrm{cm})$, fruit girth $(\mathrm{cm})$, average fruit weight $(\mathrm{g})$, and fruit yield (ton/ha). Additionally, the cost of production, gross and net returns per hectare and the benefit-cost ratio was calculated for economic analysis of cucumber under Albizia lebbeck, Melia azedarach, and Leucaena leucocephala woodlots agroforestry and sole cropping cultivation.

\section{Statistical analysis}

Two-factors "Analysis of Variance" (ANOVA) was done using the computer-based MSTAT-C statistical data analysis software. The mean data of treatments and combined effects were separated by the (DMRT) Duncan's Multiple Range Test (Gomez and Gomez, 1984).

\section{Results}

\section{The effect of cucumber production systems on growth, yield contributing characters and yield}

Cucumber is grown excellently in association with Albizia lebbeck, Melia azedarach, and Leucaena leucocephala woodlots compared to sole cropping (control treatment) (Table 3). At the very initial stage $(15$ DAS), the tallest plant $(38.11 \mathrm{~cm})$ was observed in cucumber under Leucaena leucocephala $\left(\mathrm{T}_{4}\right)$ which was identical to $\left(\mathrm{T}_{2}=35.67 \mathrm{~cm}\right)$ and $\left(\mathrm{T}_{3}=34.22 \mathrm{~cm}\right)$. The shortest plant $(23.44 \mathrm{~cm})$ was found in the sole cropping of cucumber $\left(\mathrm{T}_{1}\right)$. At $30 \mathrm{DAS}$, the tallest plant $(171.60 \mathrm{~cm})$ was recorded in $\left(\mathrm{T}_{4}\right)$ cucumber under Leucaena leucocephala, which was similar to $\left(\mathrm{T}_{3}=169.70 \mathrm{~cm}\right)$, and the shortest plant $(138.70 \mathrm{~cm})$ was originated in $\left(\mathrm{T}_{1}\right)$ sole cropping of cucumber. Finally, the tallest plant $(310.40 \mathrm{~cm})$ was noted in $T_{4}$, and the shortest plant $(260.00 \mathrm{~cm})$ was recorded in $\mathrm{T}_{1}$ at 45 DAS. The leaves plant ${ }^{-1}$ was perceived significantly maximum (7.33, 44.00, and 93.22 at $15,30$, and $45 \mathrm{DAS})$ in open field condition $\left(\mathrm{T}_{1}\right)$ and the minimum number of leaf plant ${ }^{-}$ 1 (5.89, 23.67, and 61.44 at 15, 30, and 45 DAS) in cucumber under Leucaena leucocephala $\left(\mathrm{T}_{4}\right)$. For leaf length of cucumber, the highest leaf length $(8.12,12.96$, and $17.87 \mathrm{~cm}$ at 15, 30, and $45 \mathrm{DAS}$ ) was taken from $\left(\mathrm{T}_{2}\right)$ cucumber under Albizia lebbeck based agroforestry practice, besides the lowest leaf length $(6.53,12.10$, and $15.97 \mathrm{~cm}$ at 15,30 and 45 DAS) was measured from $\left(T_{1}\right)$ sole cropping of cucumber. The leaf breadth was significantly varied due to different woodlots agroforestry practices along with mono-cropping of cucumber. The leaf breadth was calculated the highest $(8.83,15.79$, and $22.58 \mathrm{~cm}$ at 15,30 , and $45 \mathrm{DAS})$ in $\left(\mathrm{T}_{3}\right)$ cucumber under Melia azedarach. In contrast, the lowest leaf breadth $(6.63,13.14$, and $18.97 \mathrm{~cm}$ at 15,30 and $45 \mathrm{DAS})$ in $\left(\mathrm{T}_{2}\right)$ cucumber under Albizia lebbeck. 
Table 3. The effect of cucumber production practices on plant height, number of leaf plant ${ }^{-1}$, leaf length, and breadth at different DAS

\begin{tabular}{c|c|c|c|c|c|c|c|c|c|c|c|c}
\hline \multirow{3}{*}{ Treatments } & \multicolumn{4}{|c|}{ Plant height $(\mathbf{c m})$} & \multicolumn{3}{c|}{ Leaf plant $^{-1}$} & \multicolumn{3}{c|}{ Leaf length $(\mathbf{c m})$} & \multicolumn{3}{|c}{ Leaf breadth $(\mathbf{c m})$} \\
\cline { 2 - 11 } & $\mathbf{1 5}$ & $\mathbf{3 0}$ & $\mathbf{4 5}$ & $\mathbf{1 5}$ & $\mathbf{3 0}$ & $\mathbf{4 5}$ & $\mathbf{1 5}$ & $\mathbf{3 0}$ & $\mathbf{4 5}$ & $\mathbf{1 5}$ & $\mathbf{3 0}$ & $\mathbf{4 5}$ \\
& DAS & DAS & DAS & DAS & DAS & DAS & $\mathbf{D A S}$ & DAS & DAS & DAS & DAS & DAS \\
\hline $\mathrm{T}_{1}$ & $23.44 \mathrm{~b}$ & $138.7 \mathrm{c}$ & $260.0 \mathrm{~d}$ & $7.33 \mathrm{a}$ & $44.00 \mathrm{a}$ & $93.22 \mathrm{a}$ & $6.53 \mathrm{~b}$ & $12.10 \mathrm{~b}$ & $15.97 \mathrm{c}$ & $6.83 \mathrm{~b}$ & $14.12 \mathrm{~b}$ & $20.07 \mathrm{~b}$ \\
$\mathrm{~T}_{2}$ & $35.67 \mathrm{a}$ & $153.8 \mathrm{~b}$ & $289.3 \mathrm{~b}$ & $6.22 \mathrm{ab}$ & $28.89 \mathrm{~b}$ & $71.44 \mathrm{~b}$ & $8.12 \mathrm{a}$ & $12.96 \mathrm{a}$ & $17.87 \mathrm{a}$ & $6.63 \mathrm{~b}$ & $13.14 \mathrm{c}$ & $18.87 \mathrm{c}$ \\
$\mathrm{T}_{3}$ & $34.22 \mathrm{a}$ & $169.7 \mathrm{a}$ & $270.7 \mathrm{c}$ & $5.94 \mathrm{~b}$ & $25.00 \mathrm{bc}$ & $65.11 \mathrm{c}$ & $7.86 \mathrm{a}$ & $12.62 \mathrm{ab}$ & $17.06 \mathrm{~b}$ & $8.83 \mathrm{a}$ & $15.79 \mathrm{a}$ & $22.58 \mathrm{a}$ \\
$\mathrm{T}_{4}$ & $38.11 \mathrm{a}$ & $171.6 \mathrm{a}$ & $310.4 \mathrm{a}$ & $5.89 \mathrm{~b}$ & $23.67 \mathrm{c}$ & $61.44 \mathrm{~d}$ & $6.80 \mathrm{~b}$ & $12.21 \mathrm{~b}$ & $16.00 \mathrm{c}$ & $8.07 \mathrm{a}$ & $14.40 \mathrm{~b}$ & $19.96 \mathrm{~b}$ \\
\hline $\mathrm{CV} \%$ & 14.65 & 9.72 & 2.5 & 19.63 & 15.08 & 2.63 & 14.27 & 4.59 & 3.12 & 10.91 & 6.64 & 2.53 \\
\hline
\end{tabular}

In the column, figures with similar letters or without letters do not differ significantly at the $\mathrm{P} \leq 5 \%$ level by DMRT

The results of petiole length, stem girth, main stem internode length, and the number of lateral shoots plant ${ }^{-1}$ varied significantly because of different production practices presented in Table 4. Notably, the highest petiole length $(19.23 \mathrm{~cm})$ was found in cucumber under Leucaena leucocephala $\left(\mathrm{T}_{4}\right)$, and the lowest petiole length $(14.74 \mathrm{~cm})$ was observed in $\left(\mathrm{T}_{1}\right)$ sole cropping of cucumber. The stem girth $(2.66 \mathrm{~cm})$ was the maximum recorded in $\left(\mathrm{T}_{4}\right)$ cucumber under Leucaena leucocephala, followed by $(2.52 \mathrm{~cm})$ in $\left(T_{1}\right)$. In contrast, the lowest stem girth $(2.23 \mathrm{~cm})$ was recorded in $\left(T_{2}\right)$ cucumber under Albizia lebbeck, similar to $(2.27 \mathrm{~cm})$ in $\left(\mathrm{T}_{3}\right)$. The sole cropping cucumber $\left(T_{1}\right)$ gave the highest $(5.43 \mathrm{~cm})$ internode length, which was identical to $T_{2}$ and $T_{3}$, then the lowest $(4.31 \mathrm{~cm})$ internode length was calculated in $\mathrm{T}_{4}$. In the case of the number of lateral shoots, the maximum (8.78) was counted in sole cropping of cucumber $\left(\mathrm{T}_{1}\right)$, and the lowest (4.67) was determined in $\left(\mathrm{T}_{3}\right)$ cucumber under Melia azedarach.

Table 4. The effect of cucumber production practices on petiole length, stem girth, main stem internode length, and the number of lateral shoots plant ${ }^{-1}$

\begin{tabular}{c|c|c|c|c}
\hline Treatments & $\begin{array}{c}\text { Petiole length } \\
(\mathbf{c m})\end{array}$ & $\begin{array}{c}\text { Stem girth } \\
(\mathbf{c m})\end{array}$ & $\begin{array}{c}\text { Main stem internode } \\
\text { length }(\mathbf{c m})\end{array}$ & $\begin{array}{c}\text { Number of lateral } \\
\text { shoots plant }^{-1}\end{array}$ \\
\hline $\mathrm{T}_{1}$ & $14.74 \mathrm{~d}$ & $2.52 \mathrm{a}$ & $5.43 \mathrm{a}$ & $8.78 \mathrm{a}$ \\
$\mathrm{T}_{2}$ & $18.83 \mathrm{~b}$ & $2.23 \mathrm{~b}$ & $4.84 \mathrm{ab}$ & $6.67 \mathrm{~b}$ \\
$\mathrm{~T}_{3}$ & $16.58 \mathrm{c}$ & $2.27 \mathrm{~b}$ & $5.67 \mathrm{a}$ & $4.67 \mathrm{c}$ \\
$\mathrm{T}_{4}$ & $19.23 \mathrm{a}$ & $2.66 \mathrm{a}$ & $4.31 \mathrm{~b}$ & $4.78 \mathrm{c}$ \\
\hline $\mathrm{CV} \%$ & 2.01 & 8.97 & 13.67 & 14.38 \\
\hline
\end{tabular}

In the column, figures with similar letters or without letters do not differ significantly at the $\mathrm{P} \leq 5 \%$ level by DMRT

The number of fruits plant $^{-1}$ was statistically significant by the effect of different cucumber production systems (Table 5). Significantly, the highest number of fruits plant ${ }^{-1}$ (10.33) was recorded in the open field, i.e. sole cropping of cucumber $\left(\mathrm{T}_{1}\right)$ and the lowest number of fruits plant ${ }^{-1}$ (5.56) was discovered in $\left(\mathrm{T}_{3}\right)$ cucumber under Melia azedarach based agroforestry practice. Moreover, cucumber fruit length was noted statistically highest $(20.02 \mathrm{~cm})$ in $\left(\mathrm{T}_{2}\right)$ cucumber under Albizia lebbeck based agroforestry practice followed by $\left(T_{1}\right)$ and $\left(T_{4}\right)$ treatments. In contrast, the lowest $(17.89 \mathrm{~cm})$ was found in $\left(T_{3}\right)$ cucumber under Melia azedarach. The same trend was found for fruit girth as well. The 
maximum fruit weight (361.9 g) was calculated in cucumber under Albizia lebbeck $\left(\mathrm{T}_{2}\right)$ followed by $(335.8 \mathrm{~g})$ in $\mathrm{T}_{1}$ treatment; the minimum $(217.8 \mathrm{~g})$ fruit weight was taken in cucumber under Melia azedarach $\left(\mathrm{T}_{3}\right)$. Furthermore, Fruit yield was measured as the highest $(3.56 \mathrm{~kg} / \mathrm{plot})$ in $\left(\mathrm{T}_{2}\right)$ cucumber under Albizia lebbeck followed by $\mathrm{T}_{1}$ $(3.17 \mathrm{~kg} / \mathrm{plot})$ and the lowest $(1.67 \mathrm{~kg} / \mathrm{plot})$ in $\left(\mathrm{T}_{3}\right)$ cucumber under Melia azedarach. The fruit yield (5.70 tons/ha) was the maximum among the different cucumber production practices in the $\left(\mathrm{T}_{2}\right)$ treatment showed in Fig. 2.

Table 5. The effect of cucumber production practices on fruits per plant, fruit length, fruit weight, and fruit yield

\begin{tabular}{c|c|c|c|c|c}
\hline Treatments & $\begin{array}{c}\text { Fruits per } \\
\text { plant }\end{array}$ & $\begin{array}{c}\text { Fruit length } \\
(\mathbf{c m})\end{array}$ & $\begin{array}{c}\text { Fruit girth } \\
(\mathbf{c m})\end{array}$ & $\begin{array}{c}\text { Average fruit } \\
\text { weight }(\mathbf{g})\end{array}$ & $\begin{array}{c}\text { Fruit yield } \\
(\mathbf{k g} / \mathbf{p l o t})\end{array}$ \\
\hline $\mathrm{T}_{1}$ & $10.33 \mathrm{a}$ & $19.11 \mathrm{ab}$ & $14.32 \mathrm{ab}$ & $335.8 \mathrm{ab}$ & $3.17 \mathrm{ab}$ \\
$\mathrm{T}_{2}$ & $9.11 \mathrm{~b}$ & $20.02 \mathrm{a}$ & $15.57 \mathrm{a}$ & $361.9 \mathrm{a}$ & $3.56 \mathrm{a}$ \\
$\mathrm{T}_{3}$ & $5.56 \mathrm{c}$ & $17.89 \mathrm{~b}$ & $12.03 \mathrm{~b}$ & $217.8 \mathrm{c}$ & $1.67 \mathrm{c}$ \\
$\mathrm{T}_{4}$ & $6.11 \mathrm{c}$ & $18.07 \mathrm{ab}$ & $14.50 \mathrm{ab}$ & $312.7 \mathrm{~b}$ & $2.96 \mathrm{~b}$ \\
\hline $\mathrm{CV} \%$ & 14.99 & 10.44 & 12.88 & 11.32 & 13.77 \\
\hline
\end{tabular}

In the column, figures with similar letters or without letters do not differ significantly at the $\mathrm{P} \leq 5 \%$ level by DMRT

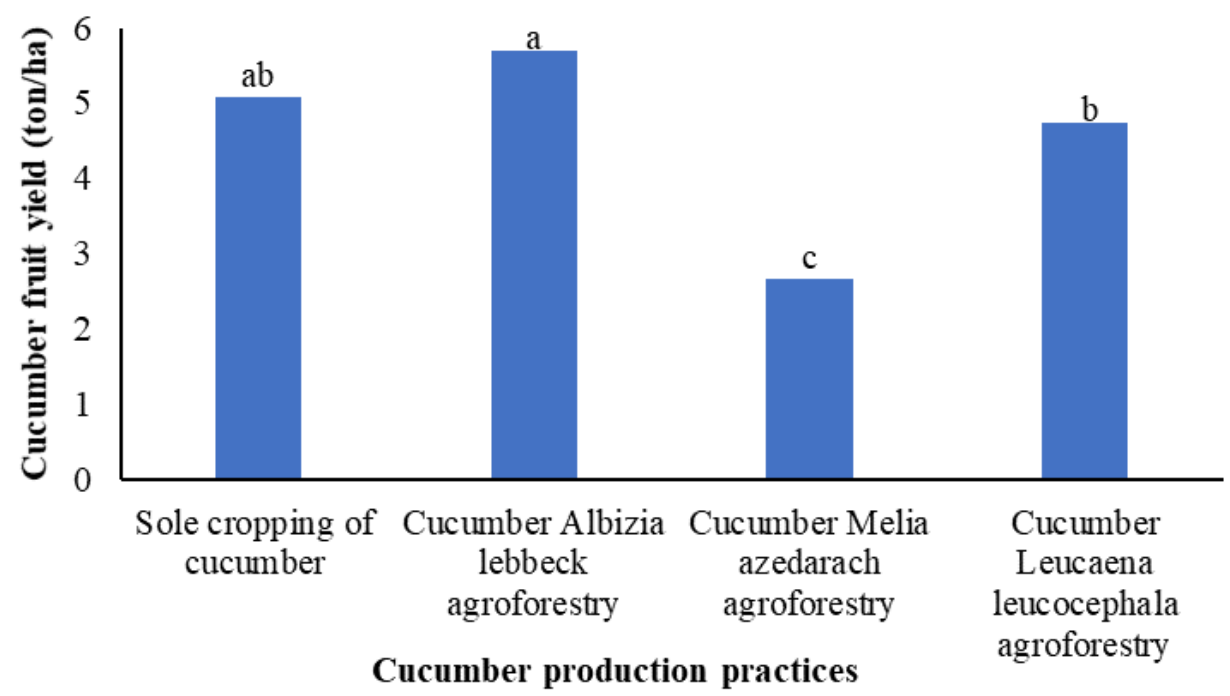

Figure 2. The effect of cucumber production practices on the fruit yield (ton/ha). In the bar, figures with similar letters or without letters do not differ significantly at the $P \leq 5 \%$ level by

$D M R T$

\section{The effect of organic mulch on the cucumber growth, yield contributing characters and yield}

The effect of organic mulch on cucumber plant height, leaf plant ${ }^{-1}$, leaf length, and breadth was statistically significant; results were shown in Table 6. Numerically, the tallest plant $(35.33 \mathrm{~cm})$ was recorded in $\mathrm{M}_{2}$ (ash mulch), and the shortest plant height $(31.58 \mathrm{~cm})$ was observed in $\mathrm{M}_{1}$ (no mulch) control treatment at 15 DAS. At 30 DAS, significantly, the tallest plant $\left(178.8 \mathrm{~cm}\right.$ ) was noted in $\mathrm{M}_{3}$ (dry water hyacinth mulch) treatment followed by 
$\mathrm{M}_{1}$ (no mulch), while the shortest plant height $(140.3 \mathrm{~cm})$ was noticed in $\mathrm{M}_{2}$ (ash mulch) treatment. Finally, at 45 DAS, considerably the tallest plant $(343.6 \mathrm{~cm})$ was recorded in $\mathrm{M}_{3}$ (dry water hyacinth mulch) treatment followed by $\mathrm{M}_{1}$ (no mulch), whereas the shortest plant $(228.5 \mathrm{~cm})$ was taken in $\mathbf{M}_{2}$ (ash mulch) treatment. The leaves plant ${ }^{-1}$ was showed insignificant at 15 and 30 DAS. The maximum leaves plant ${ }^{-1}$ (79.83) was counted in $\mathbf{M}_{2}$ (ash mulch) treatment, and the minimum leaves plant ${ }^{-1}$ (65.00) was taken in $\mathrm{M}_{1}$ (no mulch) treatment at 45 DAS respectively. Cucumber leaf length was maximum $(7.79 \mathrm{~cm}, 12.85$ $\mathrm{cm}$, and 19.03 at 15, 30 and 45 DAS) recorded in $\mathrm{M}_{3}$ (dry water hyacinth mulch) followed by $\mathrm{M}_{2}$ (ash mulch) treatment. On the other hand, minimum leaf length $(6.44 \mathrm{~cm}, 11.89 \mathrm{~cm}$, and 15.83 at 15, 30 and 45 DAS) was found in $M_{1}$ (no mulch) control treatment. The same trend of results was observed for leaf breadth at 15, 30 and 45 DAS.

Table 6. The effect of organic mulch on cucumber plant height, leaf plant ${ }^{-1}$, leaf length and breadth at different DAS

\begin{tabular}{c|c|c|c|c|c|c|c|c|c|c|c|c}
\hline \multirow{3}{*}{ Treatments } & \multicolumn{3}{|c|}{ Plant height $(\mathbf{c m})$} & \multicolumn{3}{c|}{ Leaf plant $^{-1}$} & \multicolumn{2}{c}{ Leaf length $(\mathbf{c m})$} & \multicolumn{3}{c}{ Leaf breadth (cm) } \\
\cline { 2 - 11 } & $\mathbf{1 5}$ & $\mathbf{3 0}$ & $\mathbf{4 5}$ & $\mathbf{1 5}$ & $\mathbf{3 0}$ & $\mathbf{4 5}$ & $\mathbf{1 5}$ & $\mathbf{3 0}$ & $\mathbf{4 5}$ & $\mathbf{1 5}$ & $\mathbf{3 0}$ & $\mathbf{4 5}$ \\
& DAS & DAS & DAS & DAS & DAS & DAS & DAS & DAS & DAS & DAS & DAS & DAS \\
\hline $\mathrm{M}_{1}$ & 31.58 & $156.2 \mathrm{~b}$ & $275.8 \mathrm{~b}$ & 6.75 & 30.92 & $65.00 \mathrm{c}$ & $6.44 \mathrm{~b}$ & $11.89 \mathrm{~b}$ & $15.83 \mathrm{~b}$ & $6.13 \mathrm{~b}$ & $13.13 \mathrm{~b}$ & $19.01 \mathrm{~b}$ \\
$\mathrm{M}_{2}$ & 35.33 & $140.3 \mathrm{c}$ & $228.5 \mathrm{c}$ & 6.50 & 32.00 & $79.83 \mathrm{a}$ & $7.75 \mathrm{a}$ & $12.85 \mathrm{a}$ & $15.30 \mathrm{c}$ & $8.03 \mathrm{a}$ & $14.98 \mathrm{a}$ & $18.15 \mathrm{c}$ \\
$\mathrm{M}_{3}$ & 31.67 & $178.8 \mathrm{a}$ & $343.6 \mathrm{a}$ & 5.75 & 28.25 & $73.58 \mathrm{~b}$ & $7.79 \mathrm{a}$ & $12.68 \mathrm{a}$ & $19.03 \mathrm{a}$ & $8.61 \mathrm{a}$ & $14.88 \mathrm{a}$ & $23.94 \mathrm{a}$ \\
\hline $\mathrm{CV} \%$ & 14.65 & 9.72 & 2.5 & 19.63 & 15.08 & 2.63 & 14.27 & 4.59 & 3.12 & 10.91 & 6.64 & 2.53 \\
\hline
\end{tabular}

In the column, figures with similar letters or without letters do not differ significantly at the $\mathrm{P} \leq 5 \%$ level by DMRT

The effect of organic mulch on cucumber petiole length, stem girth, main stem internode length, and the number of lateral shoot plant $^{-1}$ was statistically meaningful, and the results are provided in Table 7 . The highest petiole length $(19.38 \mathrm{~cm})$ was noted in $\mathrm{M}_{3}$ (dry water hyacinth mulch) followed by $\left(16.48 \mathrm{~cm}\right.$ ) in $\mathrm{M}_{1}$ (no mulch) treatment, and the lowest petiole length $\left(16.18 \mathrm{~cm}\right.$ ) was detected in $\mathrm{M}_{2}$ (ash mulch) treatment. The result of cucumber stem girth was analyzed statistically insignificant because of different organic mulches. The main stem internode length was calculated $(5.54 \mathrm{~cm})$, the maximum in $\mathrm{M}_{2}$ (ash mulch) treatment and the minimum $\left(4.78 \mathrm{~cm}\right.$ ) in $\mathrm{M}_{3}$ (dry water hyacinth mulch) treatment similar to $\mathrm{M}_{1}(4.87 \mathrm{~cm})$, respectively. Organic mulch affected the lateral shoot plant ${ }^{-1 ;}$ as such, the highest lateral shoot plant $^{-1}$ (7.17) was recorded in $\mathrm{M}_{2}$ (ash mulch) treatment which was identical (6.75) in $M_{1}$ treatment. Then again, the lowest number of lateral shoot plant ${ }^{-1}$ (4.75) was observed in $\mathrm{M}_{3}$ (dry water hyacinth mulch).

Table 7. The effect of organic mulch on cucumber petiole length, stem girth, main stem internode length and number of lateral shoots plant ${ }^{-1}$

\begin{tabular}{c|c|c|c|c}
\hline Treatments & $\begin{array}{c}\text { Petiole length } \\
(\mathbf{c m})\end{array}$ & $\begin{array}{c}\text { Stem girth } \\
(\mathbf{c m})\end{array}$ & $\begin{array}{c}\text { Main stem internode } \\
\text { length }(\mathbf{c m})\end{array}$ & $\begin{array}{c}\text { Number of lateral } \\
\text { shoots plant }^{-1}\end{array}$ \\
\hline $\mathrm{M}_{1}$ & $16.48 \mathrm{~b}$ & 2.43 & $4.87 \mathrm{~b}$ & $6.75 \mathrm{a}$ \\
$\mathrm{M}_{2}$ & $16.18 \mathrm{c}$ & 2.37 & $5.54 \mathrm{a}$ & $7.17 \mathrm{a}$ \\
$\mathrm{M}_{3}$ & $19.38 \mathrm{a}$ & 2.47 & $4.78 \mathrm{~b}$ & $4.75 \mathrm{~b}$ \\
\hline $\mathrm{CV} \%$ & 2.01 & 8.97 & 13.67 & 14.38 \\
\hline
\end{tabular}

In the column, figures with similar letters or without letters do not differ significantly at the $\mathrm{P} \leq 5 \%$ level by DMRT 
The cucumber fruits per plant were varied as influenced by organic mulch (Table 8). Significantly the highest fruits per plant (11.75) was found in $\mathrm{M}_{3}$ (dry water hyacinth mulch) treatment which was statistically identical to (11.17) $\mathrm{M}_{2}$ (ash mulch). Instead, the lowest fruits per plant (4.17) was observed in $\mathrm{M}_{1}$ (no mulch) control treatment. The fruit length of cucumber was also varied significantly as directly influenced by organic mulch. Substantially, the most extended fruit $\left(21.78 \mathrm{~cm}\right.$ ) was found in $\mathrm{M}_{3}$ (dry water hyacinth mulch) treatment, and the shortest fruit length $(17.09 \mathrm{~cm})$ was observed in $\mathrm{M}_{1}$ (no mulch) control treatment which was followed by $\mathrm{M}_{2}$ (ash mulch) treatment. Fruit girth of cucumber was also varied significantly, the highest fruit girth $(16.22 \mathrm{~cm})$ was measured in $\mathrm{M}_{3}$ (dry water hyacinth mulch) treatment, and the lowest $(13.14 \mathrm{~cm})$ fruit girth was taken from $M_{1}$ (no mulch) control treatment similar to $M_{2}$ (ash mulch). The highest average fruit weight $\left(377.1 \mathrm{~g}\right.$ ) was recorded in $\mathrm{M}_{3}$ (dry water hyacinth mulch) treatment, and the lowest average fruit weight (303.6 g) was recorded in $\mathrm{M}_{1}$ (no mulch) control treatment which was followed by $\mathrm{M}_{2}$ (ash mulch). The highest cucumber fruit yield (4.38 kg/plot) was observed in $\mathrm{M}_{3}$ (dry water hyacinth mulch) treatment followed by (3.53 kg/plot) in $\mathrm{M}_{2}$ (ash mulch) treatment whereas, the lowest fruit yield $(2.65 \mathrm{~kg} / \mathrm{plot})$ was detected in $\mathrm{M}_{1}$ (no mulch) control treatment. The fruit yield (7.01 tons/ha) was the highest found in $\mathrm{M}_{3}$ (dry water hyacinth mulch) treatment compared to other treatments, and the lowest (4.24 tons/ha) was observed in $\mathrm{M}_{1}$ (no mulch) control treatment (Fig. 3).

Table 8. The effect of organic mulch on the number of cucumber fruits per plant, fruit length, fruit weight and fruit yield

\begin{tabular}{c|c|c|c|c|c}
\hline Treatments & $\begin{array}{c}\text { Fruits per } \\
\text { plant }\end{array}$ & $\begin{array}{c}\text { Fruit } \\
\text { length }(\mathbf{c m})\end{array}$ & $\begin{array}{c}\text { Fruit girth } \\
(\mathbf{c m})\end{array}$ & $\begin{array}{c}\text { Average } \\
\text { fruit weight }(\mathbf{g})\end{array}$ & $\begin{array}{c}\text { Fruit yield } \\
(\mathbf{k g} / \mathbf{p l o t})\end{array}$ \\
\hline $\mathrm{M}_{1}$ & $4.17 \mathrm{~b}$ & $17.09 \mathrm{~b}$ & $13.14 \mathrm{~b}$ & $303.6 \mathrm{~b}$ & $2.65 \mathrm{~b}$ \\
$\mathrm{M}_{2}$ & $11.17 \mathrm{a}$ & $17.44 \mathrm{~b}$ & $13.21 \mathrm{~b}$ & $322.7 \mathrm{~b}$ & $3.53 \mathrm{ab}$ \\
$\mathrm{M}_{3}$ & $11.75 \mathrm{a}$ & $21.78 \mathrm{a}$ & $16.22 \mathrm{a}$ & $377.1 \mathrm{a}$ & $4.38 \mathrm{a}$ \\
\hline $\mathrm{CV} \%$ & 14.99 & 10.44 & 12.88 & 11.32 & 13.77 \\
\hline
\end{tabular}

In the column, figures with similar letters or without letters do not differ significantly at the $\mathrm{P} \leq 5 \%$ level by DMRT

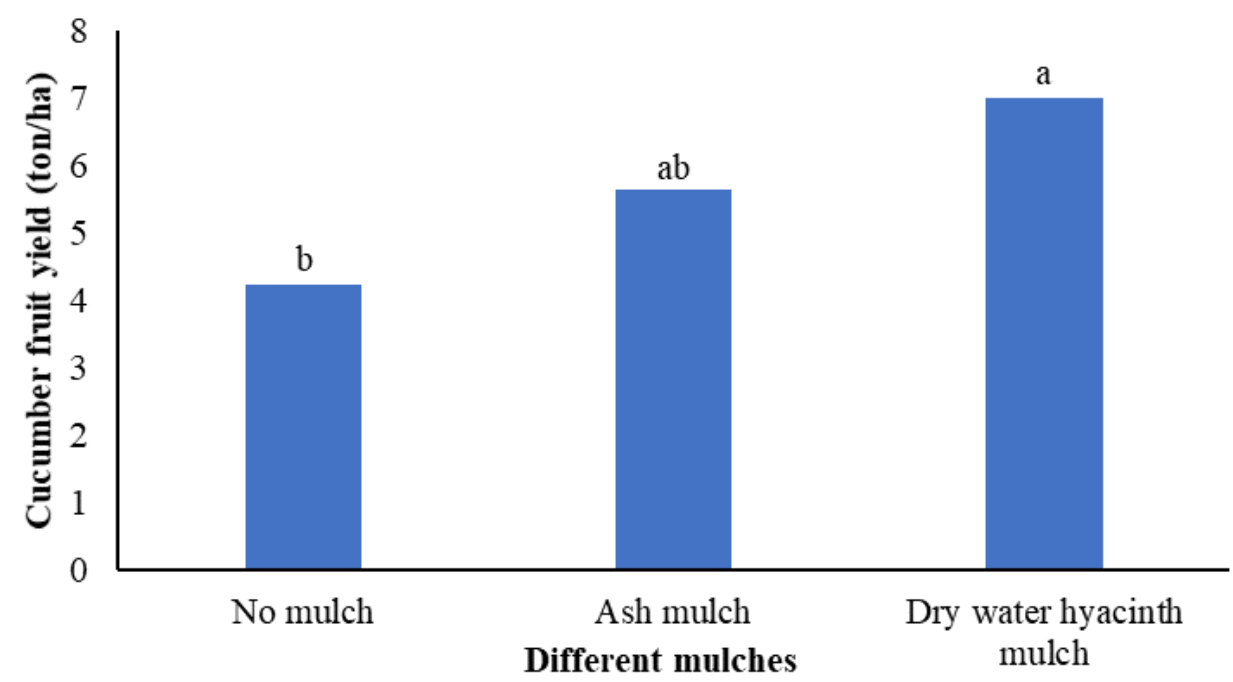

Figure 3. The effect of organic mulch on the cucumber fruit yield (ton/ha). In the bar, figures with similar letters or without letters do not differ significantly at the $P \leq 5 \%$ level by DMRT 


\section{The combined effect of cucumber production systems and organic mulch on the growth, yield contributing characters and yield}

The combined effect of cucumber production practices and organic mulch on the plant height, leaves plant $^{-1}$, leaf length, and breadth cucumber was significantly different at 15, 30 and 45 DAS (Table 9). The tallest plant $(42.33 \mathrm{~cm})$ was observed in $\mathrm{T}_{3} \mathrm{M}_{2}$ treatment combination followed by $\mathrm{T}_{4} \mathrm{M}_{1}$ treatment combination, and the shortest plant $(20.67 \mathrm{~cm})$ was recorded in $\mathrm{T}_{2} \mathrm{M}_{3}$ treatment combination at 15 DAS. In the next, at 30 and 45 DAS, the tallest plant $(195.00 \mathrm{~cm}$ and $441.70 \mathrm{~cm})$ was noted in $\mathrm{T}_{1} \mathrm{M}_{3}$ treatment combination, whereas the shortest plant $(117.30 \mathrm{~cm})$ at $30 \mathrm{DAS}$ in $\mathrm{T}_{2} \mathrm{M}_{2}$ treatment combination and $(204.3 \mathrm{~cm})$ at 45 DAS in $\mathrm{T}_{4} \mathrm{M}_{2}$ treatment combination. The leaves plant ${ }^{-1}$ at 15 DAS significantly the maximum (7.67) was documented in $\mathrm{T}_{1} \mathrm{M}_{1}$ and $\mathrm{T}_{1} \mathrm{M}_{2}$ treatment combinations and the minimum (5.00) in $\mathrm{T}_{3} \mathrm{M}_{3}$ and $\mathrm{T}_{4} \mathrm{M}_{3}$ treatment combinations. After that, at $30 \mathrm{DAS}$, the maximum leaves plant ${ }^{-1}$ (47.33) was calculated in $\mathrm{T}_{1} \mathrm{M}_{3}$ treatment combination followed by $\mathrm{T}_{1} \mathrm{M}_{1}$ and $\mathrm{T}_{1} \mathrm{M}_{2}$ and the minimum leaves plant $^{-1}$ (16.00) $\mathrm{T}_{3} \mathrm{M}_{3}$ treatment combination. Finally, at $45 \mathrm{DAS}$, the maximum leaves plant $^{-1}$ (93.70) was observed in $\mathrm{T}_{1} \mathrm{M}_{3}$ treatment combination, and the minimum leaves plant $^{-1}$ (55.33) was taken in $\mathrm{T}_{4} \mathrm{M}_{3}$ treatment combination. Leaf length (9.75 and 13.30 $\mathrm{cm}$ at 15 and $30 \mathrm{DAS}$ ) the highest was noted in $\mathrm{T}_{3} \mathrm{M}_{2}$ treatment combination, and the lowest leaf length (6.00 and $11.73 \mathrm{~cm}$ at 15 and $30 \mathrm{DAS})$ was found in $\mathrm{T}_{3} \mathrm{M}_{1}$ and $\mathrm{T}_{1} \mathrm{M}_{2}$ treatment combination. Finally, at 45 DAS, the highest leaf length $(22.60 \mathrm{~cm})$ was collected in $\mathrm{T}_{1} \mathrm{M}_{3}$ treatment combination, and the lowest leaf length $(13.70 \mathrm{~cm})$ was detected in $\mathrm{T}_{1} \mathrm{M}_{1}$ treatment combination. In the initial stage at 15 DAS, significantly, the highest leaf breadth $(10.00 \mathrm{~cm})$ was recorded in $\mathrm{T}_{4} \mathrm{M}_{3}$ treatment combination, and the lowest leaf breadth $(5.37 \mathrm{~cm})$ was measured in $\mathrm{T}_{3} \mathrm{M}_{1}$ treatment combination. Moreover, at $30 \mathrm{DAS}$, the highest leaf breadth $(16.60 \mathrm{~cm})$ was observed in $\mathrm{T}_{3} \mathrm{M}_{2}$ treatment combination, whereas the lowest leaf breadth $(11.97 \mathrm{~cm})$ was found in $\mathrm{T}_{1} \mathrm{M}_{1}$ treatment combination. At 45 DAS, the highest leaf breadth $(26.47 \mathrm{~cm})$ was calculated in $\mathrm{T}_{1} \mathrm{M}_{3}$ treatment combination, and the lowest leaf breadth $(16.77 \mathrm{~cm})$ was measured in $\mathrm{T}_{1} \mathrm{M}_{1}$ treatment combination.

The combined effect of cucumber production systems and organic mulch was significantly varied for petiole length, stem girth, main stem internode length, and the number of lateral shoots plant ${ }^{-1}$; the results epitomized in Table 10. The highest petiole length $(23.70 \mathrm{~cm})$ was recorded in $\mathrm{T}_{2} \mathrm{M}_{3}$ treatment combination, and the lowest petiole length $(12.93 \mathrm{~cm})$ was calculated in the $\mathrm{T}_{3} \mathrm{M}_{3}$ treatment combination. The stem girth $(2.80 \mathrm{~cm})$ was the maximum collected from $\mathrm{T}_{4} \mathrm{M}_{3}$ treatment combination, and the minimum $(1.97 \mathrm{~cm})$ stem girth was obtained from $\mathrm{T}_{2} \mathrm{M}_{2}$ treatment combination. The main stem internode length influenced the combined effect of cucumber production systems and organic mulch. The most extended main stem internode length $(7.00 \mathrm{~cm})$ was found in $\mathrm{T}_{3} \mathrm{M}_{2}$ treatment combination followed by $(6.03 \mathrm{~cm})$ and observed in the $\mathrm{T}_{1} \mathrm{M}_{3}$ treatment combination. The shortest main stem internode length $(3.87 \mathrm{~cm})$ was recorded in $\mathrm{T}_{4} \mathrm{M}_{3}$ treatment combination, which was statistically identical to $(4.27 \mathrm{~cm})$ found in $\mathrm{T}_{4} \mathrm{M}_{1}$ treatment combination, respectively. The number of lateral shoots plant ${ }^{-}$ ${ }^{1}$ was the maximum (10.33) was recorded in $\mathrm{T}_{1} \mathrm{M}_{1}$ treatment combination whereas, the lowest number of lateral shoots plant ${ }^{-1}$ (2.67) was noted in both $\mathrm{T}_{4} \mathrm{M}_{3}$ and $\mathrm{T}_{3} \mathrm{M}_{3}$ treatment combinations. 
Table 9. The combined effect of cucumber production practices and organic mulch on plant height, number of leaf plant ${ }^{-1}$, leaf length, and breadth at different DAS

\begin{tabular}{|c|c|c|c|c|c|c|c|c|c|c|c|c|}
\hline \multirow{2}{*}{$\begin{array}{c}\text { Treatment } \\
\text { combinations }\end{array}$} & \multicolumn{3}{|c|}{ Plant height (cm) } & \multicolumn{3}{|c|}{ Number of leaf plant ${ }^{-1}$} & \multicolumn{3}{|c|}{ Leaf length $(\mathrm{cm})$} & \multicolumn{3}{|c|}{ Leaf breadth $(\mathrm{cm})$} \\
\hline & $\begin{array}{c}15 \\
\text { DAS }\end{array}$ & $\begin{array}{c}\text { 30 } \\
\text { DAS }\end{array}$ & $\begin{array}{c}45 \\
\text { DAS }\end{array}$ & $\begin{array}{c}15 \\
\text { DAS }\end{array}$ & $\begin{array}{c}\text { 30 } \\
\text { DAS }\end{array}$ & $\begin{array}{c}45 \\
\text { DAS }\end{array}$ & $\begin{array}{c}15 \\
\text { DAS }\end{array}$ & $\begin{array}{c}\text { 30 } \\
\text { DAS }\end{array}$ & $\begin{array}{c}45 \\
\text { DAS }\end{array}$ & 15 DAS & $\begin{array}{c}\text { 30 } \\
\text { DAS }\end{array}$ & 45 DAS \\
\hline $\mathrm{T}_{1} \mathrm{M}_{1}$ & $32.00 \mathrm{a}-\mathrm{d}$ & $154.0 \mathrm{~cd}$ & $267.3 \mathrm{de}$ & $7.67 \mathrm{a}$ & $40.67 \mathrm{ab}$ & $88.67 \mathrm{~b}$ & 7.00b-d & $11.97 \mathrm{~b}$ & $13.70 \mathrm{~h}$ & $6.53 b c$ & $11.97 \mathrm{f}$ & $16.77 f$ \\
\hline $\mathrm{T}_{1} \mathrm{M}_{2}$ & $40.67 \mathrm{ab}$ & $165.7 \mathrm{bc}$ & $222.3 \mathrm{~h}$ & $7.67 \mathrm{a}$ & $44.00 \mathrm{a}$ & $57.33 \mathrm{f}$ & $6.27 \mathrm{~d}$ & $11.73 b$ & $14.87 \mathrm{~g}$ & $6.37 \mathrm{bc}$ & $12.70 \mathrm{ef}$ & $16.97 \mathrm{f}$ \\
\hline $\mathrm{T}_{1} \mathrm{M}_{3}$ & $34.33 a-d$ & $195.0 \mathrm{a}$ & $441.7 \mathrm{a}$ & $6.67 \mathrm{ab}$ & $47.33 \mathrm{a}$ & $93.7 \mathrm{a}$ & $7.13 b-d$ & $12.60 \mathrm{ab}$ & $22.60 \mathrm{a}$ & $7.60 \mathrm{~b}$ & $14.77 b-d$ & $26.47 \mathrm{a}$ \\
\hline $\mathrm{T}_{2} \mathrm{M}_{1}$ & $25.33 b-d$ & $151.7 \mathrm{c}-\mathrm{e}$ & $279.0 \mathrm{~d}$ & $6.67 \mathrm{ab}$ & $35.00 \mathrm{bc}$ & $85.67 \mathrm{~b}$ & $6.07 \mathrm{~d}$ & $11.93 b$ & $17.23 \mathrm{~cd}$ & $5.77 \mathrm{c}$ & $13.53 c-f$ & $21.43 \mathrm{c}$ \\
\hline $\mathrm{T}_{2} \mathrm{M}_{2}$ & $24.33 \mathrm{~cd}$ & $117.3 \mathrm{f}$ & $235.0 \mathrm{~g}$ & $5.67 \mathrm{ab}$ & $22.33 \mathrm{e}-\mathrm{g}$ & $62.33 \mathrm{e}$ & $6.67 \mathrm{~cd}$ & $12.83 \mathrm{ab}$ & $16.17 \mathrm{ef}$ & $6.57 \mathrm{bc}$ & $15.60 a b$ & $20.13 d$ \\
\hline $\mathrm{T}_{2} \mathrm{M}_{3}$ & $20.67 d$ & $192.3 \mathrm{ab}$ & $354.0 \mathrm{~b}$ & $6.33 \mathrm{ab}$ & $29.33 c-e$ & $66.33 \mathrm{~d}$ & $6.87 \mathrm{~b}-\mathrm{d}$ & $11.87 \mathrm{~b}$ & $20.20 \mathrm{~b}$ & $7.57 b$ & $13.23 \mathrm{~d}-\mathrm{f}$ & $26.17 \mathrm{a}$ \\
\hline $\mathrm{T}_{3} \mathrm{M}_{1}$ & $28.00 \mathrm{a}-\mathrm{d}$ & $126.7 d-f$ & $295.0 \mathrm{c}$ & $6.33 \mathrm{ab}$ & $23.33 \mathrm{~d}-\mathrm{g}$ & $78.33 c$ & $6.00 \mathrm{~d}$ & $11.83 b$ & $17.00 \mathrm{de}$ & $5.37 \mathrm{c}$ & $14.20 \mathrm{~b}-\mathrm{e}$ & $18.10 \mathrm{e}$ \\
\hline $\mathrm{T}_{3} \mathrm{M}_{2}$ & $42.33 \mathrm{a}$ & $154.0 \mathrm{~cd}$ & $252.3 \mathrm{f}$ & $6.33 \mathrm{ab}$ & $31.67 \mathrm{~cd}$ & $78.00 \mathrm{c}$ & $9.57 \mathrm{a}$ & $13.30 \mathrm{a}$ & $15.50 \mathrm{fg}$ & $9.57 \mathrm{a}$ & $16.60 \mathrm{a}$ & $17.97 \mathrm{e}$ \\
\hline $\mathrm{T}_{3} \mathrm{M}_{3}$ & $32.33 a-d$ & $135.3 d-f$ & $232.7 \mathrm{gh}$ & $5.00 \mathrm{~b}$ & $16.00 \mathrm{~g}$ & $39.00 \mathrm{~g}$ & $8.80 \mathrm{ab}$ & $12.73 \mathrm{ab}$ & $15.40 \mathrm{fg}$ & $9.27 \mathrm{a}$ & $16.57 \mathrm{a}$ & $20.53 d$ \\
\hline $\mathrm{T}_{4} \mathrm{M}_{1}$ & $41.00 \mathrm{ab}$ & 192.3ab & 261.7ef & $6.33 \mathrm{ab}$ & $24.67 d-f$ & $66.67 d$ & $6.70 \mathrm{~cd}$ & $11.83 b$ & $15.40 \mathrm{fg}$ & $6.87 b c$ & $12.83 \mathrm{ef}$ & $19.73 d$ \\
\hline $\mathrm{T}_{4} \mathrm{M}_{2}$ & $34.00 \mathrm{a}-\mathrm{d}$ & 124.0ef & $204.3 \mathrm{i}$ & $6.33 \mathrm{ab}$ & $30.00 \mathrm{c}-\mathrm{e}$ & $62.33 \mathrm{e}$ & $8.50 \mathrm{a}-\mathrm{c}$ & $13.53 \mathrm{a}$ & $14.67 \mathrm{~g}$ & $9.63 \mathrm{a}$ & $15.03 \mathrm{abc}$ & $17.53 \mathrm{ef}$ \\
\hline $\mathrm{T}_{4} \mathrm{M}_{3}$ & $39.33 a-c$ & $192.7 \mathrm{ab}$ & $346.0 \mathrm{~b}$ & $5.00 \mathrm{~b}$ & $20.33 \mathrm{fg}$ & $55.33 \mathrm{f}$ & $8.37 \mathrm{a}-\mathrm{c}$ & $13.50 \mathrm{a}$ & $17.93 \mathrm{c}$ & $10.00 \mathrm{a}$ & $15.33 \mathrm{ab}$ & $22.60 \mathrm{~b}$ \\
\hline $\mathrm{CV} \%$ & 14.65 & 9.72 & 2.5 & 19.63 & 15.08 & 2.63 & 14.27 & 4.59 & 3.12 & 10.91 & 6.64 & 2.53 \\
\hline
\end{tabular}

In the column, figures with similar letters or without letters do not differ significantly at the $\mathrm{P} \leq 5 \%$ level by DMRT 
Table 10. The combined effect of cucumber production practices and organic mulch on petiole length, stem girth, main stem internode length and number of lateral shoots plant ${ }^{-1}$

\begin{tabular}{c|c|c|c|c}
\hline $\begin{array}{c}\text { Treatment } \\
\text { combinations }\end{array}$ & $\begin{array}{c}\text { Petiole } \\
\text { length }(\mathbf{c m})\end{array}$ & $\begin{array}{c}\text { Stem } \\
\text { girth }(\mathbf{c m})\end{array}$ & $\begin{array}{c}\text { Main stem internode } \\
\text { length }(\mathbf{c m})\end{array}$ & $\begin{array}{c}\text { Number of } \\
\text { lateral shoots plant }\end{array}$ \\
\hline $\mathrm{T}_{1} \mathrm{M}_{1}$ & $15.87 \mathrm{e}$ & $2.50 \mathrm{a}-\mathrm{c}$ & $4.97 \mathrm{ab}$ & $10.33 \mathrm{a}$ \\
$\mathrm{T}_{1} \mathrm{M}_{2}$ & $17.70 \mathrm{c}$ & $2.57 \mathrm{a}-\mathrm{c}$ & $5.30 \mathrm{ab}$ & $8.00 \mathrm{~b}$ \\
$\mathrm{~T}_{1} \mathrm{M}_{3}$ & $22.93 \mathrm{~b}$ & $2.50 \mathrm{a}-\mathrm{c}$ & $6.03 \mathrm{ab}$ & $8.00 \mathrm{~b}$ \\
$\mathrm{~T}_{2} \mathrm{M}_{1}$ & $17.93 \mathrm{c}$ & $2.40 \mathrm{a}-\mathrm{c}$ & $4.83 \mathrm{ab}$ & $7.67 \mathrm{~b}$ \\
$\mathrm{~T}_{2} \mathrm{M}_{2}$ & $16.07 \mathrm{e}$ & $1.97 \mathrm{~d}$ & $5.07 \mathrm{ab}$ & $6.67 \mathrm{c}$ \\
$\mathrm{T}_{2} \mathrm{M}_{3}$ & $23.70 \mathrm{a}$ & $2.33 \mathrm{~b}-\mathrm{d}$ & $4.63 \mathrm{~b}$ & $5.67 \mathrm{c}$ \\
$\mathrm{T}_{3} \mathrm{M}_{1}$ & $14.33 \mathrm{f}$ & $2.17 \mathrm{~cd}$ & $5.40 \mathrm{ab}$ & $5.33 \mathrm{c}$ \\
$\mathrm{T}_{3} \mathrm{M}_{2}$ & $16.97 \mathrm{~d}$ & $2.40 \mathrm{a}-\mathrm{c}$ & $7.00 \mathrm{a}$ & $6.00 \mathrm{c}$ \\
$\mathrm{T}_{3} \mathrm{M}_{3}$ & $12.93 \mathrm{~g}$ & $2.23 \mathrm{~b}-\mathrm{d}$ & $4.60 \mathrm{~b}$ & $2.67 \mathrm{~d}$ \\
$\mathrm{~T}_{4} \mathrm{M}_{1}$ & $17.80 \mathrm{c}$ & $2.63 \mathrm{ab}$ & $4.27 \mathrm{~b}$ & $3.67 \mathrm{~d}$ \\
$\mathrm{~T}_{4} \mathrm{M}_{2}$ & $14.00 \mathrm{f}$ & $2.53 \mathrm{a}-\mathrm{c}$ & $4.80 \mathrm{ab}$ & $8.00 \mathrm{~b}$ \\
$\mathrm{~T}_{4} \mathrm{M}_{3}$ & $17.93 \mathrm{c}$ & $2.80 \mathrm{a}$ & $3.87 \mathrm{~b}$ & $2.67 \mathrm{~d}$ \\
\hline $\mathrm{CV}$ & 2.01 & 8.97 & 13.67 & 14.38 \\
\hline
\end{tabular}

In the column, figures with similar letters or without letters do not differ significantly at the $\mathrm{P} \leq 5 \%$ level by DMRT

The number of cucumber fruits per plant was significantly influenced by the combined effect of production practices and organic mulch (Table 11). Significantly the highest number of fruits per plant (12.33) was recorded in $\mathrm{T}_{1} \mathrm{M}_{3}$ treatment combination, which was followed by (11.67) in $\mathrm{T}_{2} \mathrm{M}_{3}$ and (11.33) in $\mathrm{T}_{1} \mathrm{M}_{2}$ treatment combination. In contrast, the lowest number of fruits per plant (4.33) was documented in $\mathrm{T}_{3} \mathrm{M}_{1}$ treatment combination. The fruit length of cucumber was found significantly different, significantly the most extended fruit length $(23.33 \mathrm{~cm})$ was found in $\mathrm{T}_{2} \mathrm{M}_{3}$ treatment combination, which was identical to $\mathrm{T}_{1} \mathrm{M}_{3}$ treatment combination $(22.17 \mathrm{~cm})$, and the shortest fruit length $(15.80 \mathrm{~cm})$ was recorded in $\mathrm{T}_{3} \mathrm{M}_{1}$ treatment combination. Similarly, the longest fruit girth $(15.83 \mathrm{~cm})$ was found in both $\mathrm{T}_{1} \mathrm{M}_{3}$, and $\mathrm{T}_{2} \mathrm{M}_{3}$ treatment combinations, which was identical to $\mathrm{T}_{1} \mathrm{M}_{2}$ treatment combination $(14.87 \mathrm{~cm})$ and the shortest fruit girth $(10.30 \mathrm{~cm})$ was recorded in $\mathrm{T}_{3} \mathrm{M}_{1}$ treatment combination. Average fruit weight was significantly varied, the highest fruit weight (395.30 g) was measured in $\mathrm{T}_{2} \mathrm{M}_{3}$ treatment combination, which was statistically identical to $(373.30 \mathrm{~cm})$ in $\mathrm{T}_{2} \mathrm{M}_{2}$ treatment combination and $(364.70 \mathrm{~cm})$ in $\mathrm{T}_{1} \mathrm{M}_{3}$ treatment combination and the lowest fruit weight $(212.70 \mathrm{~g})$ was recorded in $\mathrm{T}_{3} \mathrm{M}_{1}$ treatment combination. The fruit yield of cucumber was significantly different because of the combined effect of production systems and organic mulch. Notably, the highest cucumber fruit yield $(5.72 \mathrm{~kg} / \mathrm{plot})$ was found in $\mathrm{T}_{2} \mathrm{M}_{3}$ treatment combination, which was indistinguishable from $(5.25 \mathrm{~kg} / \mathrm{plot})$ in $\mathrm{T}_{1} \mathrm{M}_{3}$ treatment combination, and the lowest cucumber fruit yield $(1.86 \mathrm{~kg} / \mathrm{plot})$ was noted in $\mathrm{T}_{3} \mathrm{M}_{1}$ treatment combination. Furthermore, Figure 4 provided the cucumber fruit yield (ton/ha). The result showed that the highest cucumber fruit yield $(9.15$ ton/ha) was observed in $\mathrm{T}_{2} \mathrm{M}_{3}$ followed by (8.40 tons/ha) in $\mathrm{T}_{1} \mathrm{M}_{3}$ treatment combination, and the lowest cucumber fruit yield (2.98 tons/ha) was received in $\mathrm{T}_{3} \mathrm{M}_{1}$ treatment combination (Fig. 4). 
Table 11. The combined effect of cucumber production practices and organic mulch on fruits per plant, fruit length, fruit weight and fruit yield

\begin{tabular}{c|c|c|c|c|c}
\hline $\begin{array}{c}\text { Treatment } \\
\text { combinations }\end{array}$ & $\begin{array}{c}\text { Fruits per } \\
\text { plant }\end{array}$ & $\begin{array}{c}\text { Fruit length } \\
(\mathbf{c m})\end{array}$ & $\begin{array}{c}\text { Fruit girth } \\
(\mathbf{c m})\end{array}$ & $\begin{array}{c}\text { Average fruit } \\
\text { weight }(\mathbf{g})\end{array}$ & $\begin{array}{c}\text { Fruit yield } \\
(\mathbf{k g} / \mathbf{p l o t})\end{array}$ \\
\hline $\mathrm{T}_{1} \mathrm{M}_{1}$ & $6.67 \mathrm{~cd}$ & $19.30 \mathrm{bc}$ & $13.60 \mathrm{~b}$ & $294.1 \mathrm{bc}$ & $2.93 \mathrm{~cd}$ \\
$\mathrm{~T}_{1} \mathrm{M}_{2}$ & $11.33 \mathrm{ab}$ & $17.43 \mathrm{c}$ & $14.87 \mathrm{ab}$ & $328.7 \mathrm{~b}$ & $4.85 \mathrm{ab}$ \\
$\mathrm{T}_{1} \mathrm{M}_{3}$ & $12.33 \mathrm{a}$ & $22.17 \mathrm{ab}$ & $15.83 \mathrm{a}$ & $364.7 \mathrm{ab}$ & $5.25 \mathrm{a}$ \\
$\mathrm{T}_{2} \mathrm{M}_{1}$ & $5.12 \mathrm{~d}$ & $17.17 \mathrm{c}$ & $11.98 \mathrm{~cd}$ & $256.7 \mathrm{c}$ & $3.31 \mathrm{c}$ \\
$\mathrm{T}_{2} \mathrm{M}_{2}$ & $10.67 \mathrm{~b}$ & $17.00 \mathrm{c}$ & $14.21 \mathrm{ab}$ & $373.3 \mathrm{ab}$ & $4.31 \mathrm{~b}$ \\
$\mathrm{~T}_{2} \mathrm{M}_{3}$ & $11.67 \mathrm{ab}$ & $23.33 \mathrm{a}$ & $15.83 \mathrm{a}$ & $395.3 \mathrm{a}$ & $5.72 \mathrm{a}$ \\
$\mathrm{T}_{3} \mathrm{M}_{1}$ & $4.33 \mathrm{e}$ & $15.80 \mathrm{~d}$ & $10.30 \mathrm{~d}$ & $212.7 \mathrm{~d}$ & $1.86 \mathrm{~d}$ \\
$\mathrm{~T}_{3} \mathrm{M}_{2}$ & $5.43 \mathrm{~d}$ & $16.97 \mathrm{c}$ & $11.37 \mathrm{~cd}$ & $271.2 \mathrm{bc}$ & $2.18 \mathrm{~cd}$ \\
$\mathrm{~T}_{3} \mathrm{M}_{3}$ & $6.38 \mathrm{~cd}$ & $19.73 \mathrm{bc}$ & $12.43 \mathrm{c}$ & $285.4 \mathrm{bc}$ & $2.47 \mathrm{~cd}$ \\
$\mathrm{~T}_{4} \mathrm{M}_{1}$ & $6.33 \mathrm{~cd}$ & $17.50 \mathrm{~cd}$ & $12.83 \mathrm{c}$ & $246.9 \mathrm{c}$ & $2.89 \mathrm{~cd}$ \\
$\mathrm{~T}_{4} \mathrm{M}_{2}$ & $7.67 \mathrm{c}$ & $16.97 \mathrm{c}$ & $13.37 \mathrm{~b}$ & $312.3 \mathrm{~b}$ & $3.77 \mathrm{c}$ \\
$\mathrm{T}_{4} \mathrm{M}_{3}$ & $9.33 \mathrm{~b}$ & $20.90 \mathrm{~b}$ & $13.95 \mathrm{~b}$ & $343.6 \mathrm{~b}$ & $3.88 \mathrm{c}$ \\
\hline $\mathrm{CV} \%$ & 14.99 & 10.44 & 12.88 & 11.32 & 13.77 \\
\hline
\end{tabular}

In the column, figures with similar letters or without letters do not differ significantly at the $\mathrm{P} \leq 5 \%$ level by DMRT

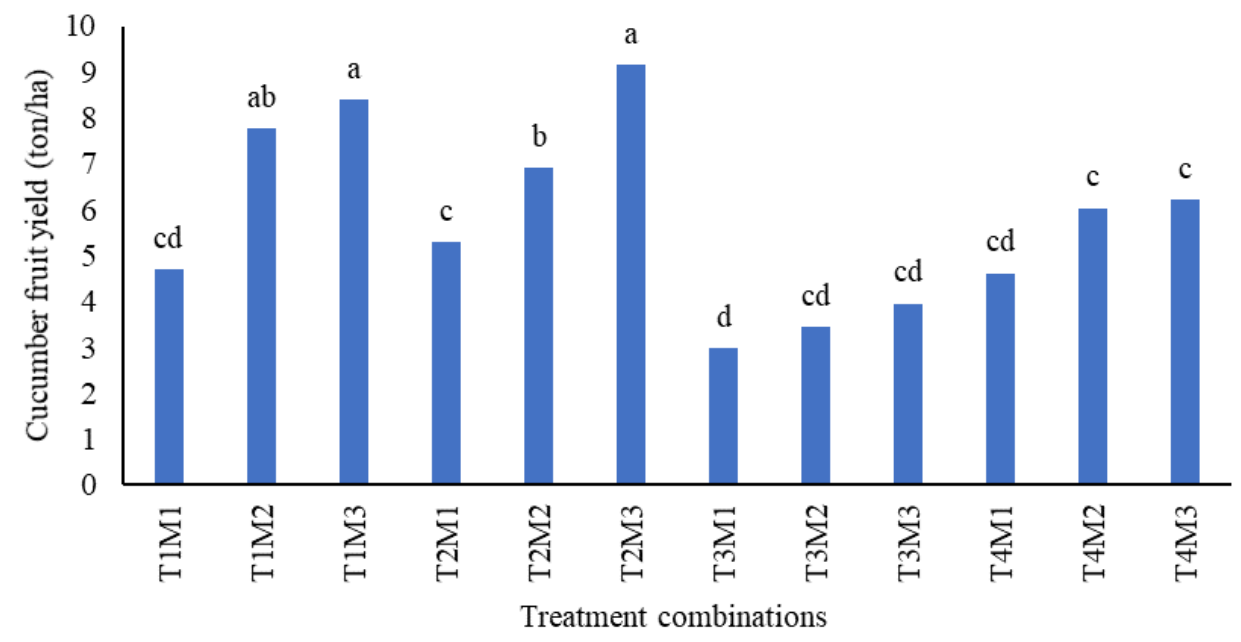

Figure 4. The combined effect of cucumber production practices and organic mulch on the fruit yield (ton/ha). In the bar, figures with similar letters or without letters do not differ significantly at the $P \leq 5 \%$ level by DMRT

Cost and benefit analysis of cucumber production under Albizia lebbeck, Melia azedarach, and Leucaena leucocephala woodlot-based agroforestry practices and sole cropping

The cost of production, gross \& net return, and benefit-cost ratio of cucumber grown under Albizia lebbeck, Melia azedarach, Leucaena leucocephala woodlots agroforestry practices and sole cropping cucumber were calculated according to market prices, and results were displayed in Table 12 and Appendix 1. The values in Appendix 1 indicated that the total cost of production was the highest (US\$2342.00 per ha) found in $\left(\mathrm{T}_{2}\right)$ 
cucumber under Albizia lebbeck based agroforestry practice followed by $\left(\mathrm{T}_{4}\right)$ cucumber under Leucaena leucocephala based agroforestry practice (US\$2318.00 per ha). The lowest cost of production was observed in $\left(T_{1}\right)$ cucumber sole cropping (US\$ 1892.00 per ha). The highest value of the gross return (US\$ 6757.00 per ha) was obtained from $\left(\mathrm{T}_{2}\right)$ cucumber under Albizia lebbeck based agroforestry practice. In contrast, the lowest value of the gross return (US\$2095.00 per ha) was acquired from $\left(T_{1}\right)$ cucumber sole cropping. The net return (US\$ 4415.00 per ha) was comparatively the highest taken in $\left(\mathrm{T}_{2}\right)$ cucumber under Albizia lebbeck based agroforestry practice. Simultaneously, the lowest net return (US\$203.00 per ha) was received from $\left(\mathrm{T}_{1}\right)$ cucumber sole cropping. The highest benefit-cost ratio (2.89) was recorded in $\left(\mathrm{T}_{2}\right)$ cucumber under Albizia lebbeck based agroforestry practice, followed by (2.43) in $\left(\mathrm{T}_{3}\right)$ cucumber under Melia azedarach based agroforestry practice, and the lowest benefit-cost ratio (1.11) was noted in $\left(\mathrm{T}_{1}\right)$ cucumber sole cropping.

Table 12. The gross return, the net return, and benefit-cost ratio (BCR) of cucumber production under Albizia lebbeck, Melia azedarach, Leucaena leucocephala woodlot-based agroforestry systems and sole cropping

\begin{tabular}{|c|c|c|c|c|c|c|c|c|}
\hline \multirow[b]{2}{*}{ Treatment } & \multicolumn{4}{|c|}{ Return (US\$/ha) } & \multirow{2}{*}{$\begin{array}{c}\text { Gross } \\
\text { return } \\
(\$ / \mathrm{ha}) \\
\end{array}$} & \multirow{2}{*}{\begin{tabular}{|c} 
Total cost of \\
production \\
$(\$ / \mathrm{ha}$
\end{tabular}} & \multirow{2}{*}{$\begin{array}{c}\text { Net } \\
\text { return } \\
(\$ / h a\end{array}$} & \multirow[b]{2}{*}{ BCR } \\
\hline & Cucumber & \begin{tabular}{|l|} 
Albizia \\
lebbeck
\end{tabular} & $\begin{array}{c}\text { Melia } \\
\text { azedarach }\end{array}$ & \begin{tabular}{|c} 
Leucaena \\
leucocephala
\end{tabular} & & & & \\
\hline $\mathrm{T}_{1}$ & 20950 & & & & 2095.00 & 1892.00 & 203 & 1.11 \\
\hline $\mathrm{T}_{2}$ & 2345.00 & 4412.00 & & & 6757.00 & 2342.00 & 4415 & 2.89 \\
\hline $\mathrm{T}_{3}$ & 1100.00 & & 4471.00 & & 5571.00 & 2289.00 & 3282 & 2.43 \\
\hline $\mathrm{T}_{4}$ & 1950.00 & & ...... & 3529.00 & 5479.00 & 2318.00 & 3161 & 2.36 \\
\hline
\end{tabular}

Note: Market price of cucumber fruit (US\$ 0.41/kg), Albizia lebbeck (US\$ 4.71/Tree/Year), Melia azedarach (US\$ 5.29/Tree/Year), Leucaena leucocephala (US\$ 4.11/Tree/Year)

\section{Discussion}

The research indicated that the commercial vegetable cucumber would perform significantly as an intercrop under different woodlots-based agroforestry and sole cropping influenced by organic mulch. The cucumber growth was found more prominent under partially shaded conditions compared to open field conditions. The reason for the outcome can be summarized as follows:

The Albizzia lebbeck tree provides adequate shade, which aids in retaining water in the cucumber during harvesting. On the other hand, this tree acts as a soil binding agent, which aids in preserving soil properties. Furthermore, the study shows that water hyacinth has a synergistic interaction with Albizzia lebbeck. The water hyacinth combination was apparent not only with Albizzia lebbeck but also with other trees. Such a result was not observed with the control group. The reason for this is that in a scorching climate, the water hyacinth dries up without shade and is thus unable to show its impact. Mainly the vegetative growth was boosted in cucumber under Leucaena leucocephala based agroforestry practice because the transpiration rate was lower. Chauhan et al. (2013) found that regardless of the crop used in the experiment, the transpiration (E) intensity of crops was lowest in the shade, resulting in higher water usage performance in the shade than in the open condition. Furthermore, the dry water hyacinth mulch also enhanced the growth of cucumber effectively. Vidya and Girish (2014) reported that water hyacinth 
application in crop fields acted as a facilitator for the crop's growth and development and improved soil fertility.

Moreover, Yaghi et al. (2013) deduced that cucumber production could be enhanced by applying plastic mulch and drip irrigation techniques, although plastic mulching is harmful to the environment. Hence, it would be more environmentally sound to use organic mulch for cucumber production.

For the cucumber reproductive growth, i.e. fruit length, girth, weight, and yield, we found the highest outcome in cucumber under Albizia lebbeck based agroforestry practice. Pervin et al. (2015) mentioned that mustard oil was cropped successfully with increased production under the Albizia lebbeck wood producing tree agroforestry system. According to Oyebamiji et al. (2017), Albizia lebbeck deciduous timber tree had a high potential to improve annual vegetable yield. Lenhard et al. (2013) reported that plants below $70 \%$ of shading had higher total rates of chlorophyll, leaf area and weight ratios. The findings showed that both the ash mulch and dry water hyacinth mulch had performed a crucial, active substantial function for cucumber production. According to Ranjan et al. (2017), organic materials would raise soil nutrients, preserves optimal soil temperature, and enhances the physical, chemical, and biological properties of soil.

The cucumber under Albizia lebbeck agroforestry practice with dry water hyacinth mulch combinedly create a valuable production opportunity in the present research. As compared to the conventional cucumber production practice with an average ( $6.83 \mathrm{ton} / \mathrm{ha}$ ) fruit yield production (Annon, 2018), our study finds a 25\% higher cucumber fruit yield (9.15 ton/ha) (Fig. 5).

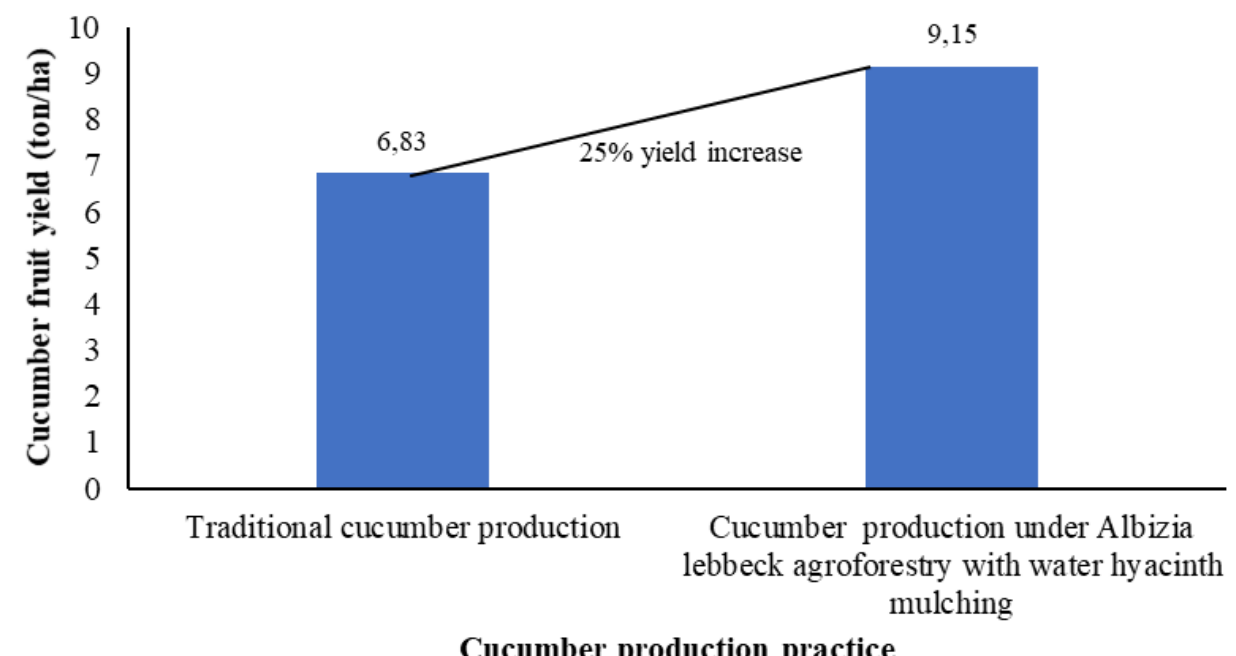

Figure 5. Cucumber fruit yield (ton/ha) comparison between conventional practice and the present research practice

From the economic point of view, in the research findings, we found the benefit-cost ratio of cucumber production under Albizia lebbeck agroforestry practice (2.89), which was higher than Melia azedarach and Leucaena leucocephala agroforestry practice along with sole cropping of cucumber. Thus, commercial cucumber production under Albizia lebbeck woodlots could bring a considerable return to the cucumber cultivators being the cost-effective solution. Amin et al. (2021) mentioned that the highest benefit-cost ratio (2.14) was found in potato grown under a mango-based agroforestry production system 
that was $20 \%$ more than the mono-cropping of crop cultivation. Compared to current farming strategies, this research would come up with a better cost-effective and environmental strategy.

\section{Conclusions}

The experimental results reveal that cucumber can be grown successfully under Albizia lebbeck, Melia azedarach, and Leucaena leucocephala woodlots-based agroforestry practice to compare with conventional mono cropping cultivation. Cucumber production was the highest in Albizia lebbeck agroforestry practice by applying the dry water hyacinth mulch. This production practice increases yield performance to a higher state than traditional cucumber cultivation. It can be concluded that the cucumber under Albizia lebbeck agroforestry practice would enhance the benefit-cost ratio significantly. This production practice is highly beneficial to cucumber cultivating farmers. Furthermore, it is recommended to test cucumber in the vacant space of fruit and forestry tree-based agroforestry practice in future assessment with other kinds of organic mulch.

Acknowledgements. The authors would like to convey optimistic gratefulness to the Agroforestry and Environment Department of HSTU, Dinajpur-5200, Bangladesh. The authors would like to take the opportunity to express their heartiest respect, deepest gratitude, and profound appreciation to all the Faculty of Environmental Management staff (PSU) Prince of Songkla University. They also appreciate the Research and Development section (RDO) of Prince of Songkla University, HatYai, 90110, Songkhla, Thailand. The authors would like to thank Arup Kumar Biswas, deputy director of the Ministry of Power, Energy, and Mineral Resources of the People's Republic of Bangladesh, to assist with the English.

\section{REFERENCES}

[1] Amin, M. H. A., Bormon, S. C., Kajal, M. (2017a): Organic production of tomato under multipurpose tree-based agroforestry as influenced by mulching. - Bangladesh Research Publications Journal 12: 222-231.

[2] Amin, M. H. A., Roy, J. P., Rahman, M. S., Kajal, M. (2017b): Economic performance of onion under Albizia lebbeck, Melia azedarach and Leucaena leucocephala based agroforestry systems. - Journal of Innovation \& Development Strategy 11(1): 1-8.

[3] Amin, M. H. A., Das, B. K., Akter, M. M., Thainiramit, P., Jutidamrongphan, W., Techato, K. A., Sangkakool, T. (2021): Economic feasibility of potato production influenced by intra-row plant spacing under mango-based agroforestry system. - Australian Journal of Crop Science 15(01): 58-66. doi: 10.21475/ajcs.21.15.01.2602.

[4] Anonymous (2018): Yearbook of Agricultural Statistics-2018, 30 ${ }^{\text {th }}$ Series. - Bangladesh Bureau of Statistics (BBS), Statistics and Informatics Division(SID), Ministry of Planning Government of the People's Republic of Bangladesh.

[5] Arai, Y., Watanabe, S., Kimira, M., Shimoi, K., Mochizuki, R., Kinae, N. (2000): Dietary Intakes of Flavonols, Flavones and Isoflavones by Japanese Women and the Inverse Correlation between Quercetin Intake and Plasma LDL Cholesterol Concentration. - The Journal of Nutrition 130: 2243-2250. https://doi.org/10.1093/jn/130.9.2243.

[6] Brammer, H., Antoine, J., Kassam, A. H., van Velthuizen, H. T. (1988): Land resource appraisal of Bangladesh for agricultural development. Report 2: Agroecological regions of Bangladesh. - Rome (Italy) FAO.

[7] Cadavid, L. F., El-Sharkawy, M. A., Acosta, A., Sánchez, T. (1998): Long-term effects of mulch, fertilization and tillage on cassava grown in sandy soils in northern Colombia. Field Crops Research 57(1): 45-56. https://doi.org/10.1016/S0378-4290(97)00114-7. 
[8] Chakraborty, M., Haider, M. Z., Rahaman, M. M. (2015): Socio-Economic Impact of Cropland Agroforestry: Evidence from Jessore District of Bangladesh. - International Journal of Research in Agriculture and Forestry 2: 11-20.

[9] Chauhan, S. K., Dhillon, W. S., Singh, N., Sharma, R. (2013): Physiological Behaviour and Yield Evaluation of Agronomic crops under Agri-horti-silviculture system. - International Journal of Plant Research 3(1): 1-8. doi:10.5923/j.plant.20130301.01.

[10] FAO (Food and Agricultural Organization) (2013): Synthesis of Guiding Principles on Agriculture Programming for Nutrition. - http://www.fao.org/3/aq194e/aq194e.pdf (Accessed 2020 Dec 20).

[11] Garrity, D. P. (2004): Agroforestry and the achievement of the Millennium Development Goals. - Agroforestry Systems 61: 5-17.

[12] Gomez, K. A., Gomez, A. A. (1984): Statistical Procedures for Agricultural Research, $2^{\text {nd }}$ Edition. - John Wiley \& Sons, New York.

[13] Hossain, S. A. A. M., Wang, L., Liu, H. (2018): Improved greenhouse cucumber production under deficit water and fertilization in Northern China. - Journal of Agricultural and Biological Engineering 11(4): 58-64.

[14] Hu, F. B. (2003): Plant-based foods and prevention of cardiovascular disease: an overview. - The American journal of clinical nutrition 78: 544S-551S. https://doi.org/10.1093/ajen/78.3.544S.

[15] Izac, A.-M. N., Sanchez, P. A. (2001): Towards a natural resource management paradigm for international agriculture: the example of agroforestry research. - Agricultural Systems 69: 5-25. https://doi.org/10.1016/S0308-521X(01)00015-4.

[16] Lenhard, N. R., de Paiva Neto, V. B., de Paula Quintao Scalon, S., de Alvarenga, A. A. (2013): Growth of Caesalpinia ferrea seedlings under different shading levels. - Pesquisa Agropecuária Tropical 43(2): 178-186. https://doi.org/10.1590/S198340632013000200012.

[17] Maikhuri, R. K., Semwal, R. L., Rao, K. S., Singh, K., Saxena, K. G. (2000): Growth and ecological impacts of traditional agroforestry tree species in Central Himalaya, India. Agroforestry Systems 48: 257-271. https://doi.org/10.1023/A:1006344812127.

[18] Marinari, S., Masciandaro, G., Ceccanti, B., Grego, S. (2007): Evolution of soil organic matter changes using pyrolysis and metabolic indices: A comparison between organic and mineral fertilization. - Bioresource Technology 98: 2495-2502. https://doi.org/10.1016/j.biortech.2006.09.001.

[19] Mukherjee, P. K., Nema, N. K., Maity, N., Sarkar, B. K. (2013): Phytochemical and therapeutic potential of cucumber. - Fitoterapia 84: 227-236. http://dx.doi.org/10.1016/j.fitote.2012.10.003.

[20] Ntalli, N. G., Cottiglia, F., Bueno, C. A., Alché, L. E., Leonti, M., Vargiu, S., Bifulco, E., Menkissoglu-Spiroudi, U., Caboni, P. (2010): Cytotoxic Tirucallane Triterpenoids from Melia azedarach Fruits. - Molecules 15: 5866-5877. https://doi.org/10.3390/molecules15095866.

[21] Olfati, J. A., Peyvast, G., Nosrati-Rad, Z. (2008): Organic Mulching on Carrot Yield and Quality. - International Journal of Vegetable Science 14(4): 362-368. https://doi.org/10.1080/19315260802303404.

[22] Oyebamiji, N. A., Babalola, O. A., Aduradola, A. M. (2017): Decomposition and nitrogen release patterns of Parkia biglobosa and Albizia lebbeck leaves with nitrogen fertilizer for maize production in Sudan Savanna Alfisol of Nigeria. - Journal of Tropical Forestry and Environment 7(1): 54-64.

[23] Pervin, R., Hossain, M. S., Rahman, M. M., Wadud, M. A., Rahman, G. M. M. (2015): Growth and yield performance of mustard under kalokoroi (Albizia lebbeck) based cropland agroforestry system. - Journal of Agroforestry and Environment 9(1\&2): 1-6.

[24] Rahman, S. A., Imam, M. H., Snelder, D. J., Sunderland, T. (2012): Agroforestry for Livelihood Security in Agrarian Landscapes of the Padma Floodplain in Bangladesh. Small-scale Forestry 11: 529-538. https://doi.org/10.1007/s11842-012-9198-y. 
[25] Rahman, M. A., Tani, M., Asahiro, K., Ullah, S. A. (2017): Species Composition, Diversity and Productivity of Homesteads in Southeastern Bangladesh. - Small-scale Forestry 16: 295-309. https://doi.org/10.1007/s11842-016-9356-8.

[26] Rajasree, R. S., Sibi, P. I., Francis, F., William, H. (2016): Phytochemicals of Cucurbitaceae family - A review. - International Journal of Pharmacognosy and Phytochemical Research 8: 113-123.

[27] Ranjan, P., Patle, G. T., Prem, M., Solanke, K. R. (2017): Organic Mulching-A Water Saving Technique to Increase the Production of Fruits and Vegetables. - Current Agriculture Research Journal 5(3): 371-380. http://dx.doi.org/10.12944/CARJ.5.3.17.

[28] Rashid, M. M. (1999): Sabgi Biggan (in Bangla). - Rashid Publishing House, Dhaka.

[29] Reppin, S., Kuyah, S., de Neergaard, A., Oelofse, M., Rosenstock, T. S. (2020): Contribution of agroforestry to climate change mitigation and livelihoods in Western Kenya. - Agroforestry Systems 94: 203-220. https://doi.org/10.1007/s10457-019-00383-7.

[30] Sharma, R. R., Singh, R., Singh, D., Gupta, R. K. (2008): Influence of row covers and mulching interaction on leaf physiology, fruit yield and albinism incidence in 'Sweet Charlie'strawberry (Fragaria $\mathrm{x}$ ananassa Duch.). - Fruits 63: 103-110. https://doi.org/10.1051/fruits:2007052.

[31] Sharmin, A., Rabbi, S. A. (2016): Assessment of Farmers' Perception of Agroforestry Practices in Jhenaidah District of Bangladesh. - Journal of Agriculture and Ecology Research International 6(4): 1-10. doi:10.9734/JAERI/2016/21760.

[32] Singh, R., Sharma, R. R., Goyal, R. K. (2007): Interactive effects of planting time and mulching on 'Chandler'strawberry (Fragaria $\times$ ananassa Duch.). - Scientia Horticulturae 111: 344-351. https://doi.org/10.1016/j.scienta.2006.11.002.

[33] Sinkevičienè, A., Jodaugienè, D., Pupalienè, R., Urbonienè, M. (2009): The influence of organic mulches on soil properties and crop yield. - Agronomy Research 7: 485-491.

[34] Sønsteby, A., Nes, A., Måge, F. (2004): Effects of bark mulch and NPK fertilizer on yield, leaf nutrient status and soil mineral nitrogen during three years of strawberry production. Acta Agriculturae Scandinavica, Section B-Soil \& Plant Science 54(3): 128-134. https://doi.org/10.1080/09064710410030276.

[35] Teame, G., Tsegay, A., Abrha, B. (2017): Effect of organic mulching on soil moisture, yield, and yield contributing components of sesame (Sesamum indicum L.). - International Journal of Agronomy 2017: 1-6. https://doi.org/10.1155/2017/4767509.

[36] Trichopoulou, A., Martínez-González, M. A., Tong, T. Y., Forouhi, N. G., Khandelwal, S., Prabhakaran, D., Mozaffarian, D., de Lorgeril, M. (2014): Definitions and potential health benefits of the Mediterranean diet: views from experts around the world. - BMC medicine 12: 112. https://doi.org/10.1186/1741-7015-12-112.

[37] van Noordwijk, M., Bizard, V., Wangpakapattanawong, P., Tata, H. L., Villamor, G. B., Leimona, B. (2014): Tree cover transitions and food security in Southeast Asia. - Global Food Security 3: 200-208. https://doi.org/10.1016/j.gfs.2014.10.005.

[38] Vidya, S., Girish, L. (2014): Water hyacinth as a green manure for organic farming. International Journal of Research in Applied Natural and Social Sciences 2(6): 65-72.

[39] Vishnukanta, Rana, A. C. (2010): Evaluation of hydroalcoholic extract of Melia azedarach Linn roots for analgesic and anti-inflammatory activity. - International Journal of Phytomedicine 2(3): 341-244.

[40] WHO (World Health Organization) (2003): Diet, nutrition, and the prevention of chronic diseases: report a joint WHO/FAO expert consultation. - WHO Technical Report Series, No. 916.

[41] World Food Summit (1996): Report of the World Food Summit. - Rome, Italy.

[42] Xu, X., Inubushi, K., Sakamoto, K. (2006): Effect of vegetations and temperature on microbial biomass carbon and metabolic quotients of temperate volcanic forest soils. Geoderma 136: 310-319. https://doi.org/10.1016/j.geoderma.2006.03.045. 
[43] Yaghi, T., Arslan, A., Naoum, F. (2013): Cucumber (Cucumis sativus, L.) water use efficiency (WUE) under plastic mulch and drip irrigation. - Agricultural water management 128: 149-157. https://doi.org/10.1016/j.agwat.2013.06.002.

[44] Yang, Y. J., Dungan, R. S., Ibekwe, A. M., Valenzuela-Solano, C., Crohn, D. M., Crowley, D. E. (2003): Effect of organic mulches on soil bacterial communities one year after application. - Biology and Fertility of Soils 38: 273-281. doi: 10.1007/s00374-003-06399. 


\section{APPENDIX}

Appendix 1. The production cost of cucumber under Albizia lebbeck, Melia azedarach, and Leucaena leucocephala woodlot-based agroforestry systems along with sole cropping (average of one year)

\begin{tabular}{|c|c|c|c|c|c|c|c|c|c|c|c|c|c|c|}
\hline \multirow[b]{3}{*}{ Treatment } & \multicolumn{9}{|c|}{ Input cost } & \multirow{3}{*}{$\begin{array}{c}\text { Total } \\
\text { input } \\
\text { cost } \\
\text { (US\$/ha) }\end{array}$} & \multicolumn{3}{|c|}{ Overhead cost } & \multirow{3}{*}{$\mid \begin{array}{c}\text { Total cost } \\
\text { of } \\
\text { production } \\
\text { (US\$ /ha) }\end{array}$} \\
\hline & \multicolumn{3}{|c|}{$\begin{array}{c}\text { Non-material cost } \\
\text { (US\$/ha) }\end{array}$} & \multicolumn{6}{|c|}{ Material cost (US\$/ha) } & & \multirow{2}{*}{$\begin{array}{c}\text { Interest of } \\
\text { input cost } \\
@ 8 \% \text { for } \\
\text { the crop } \\
\text { season } \\
\text { (US\$/ha) }\end{array}$} & \multirow{2}{*}{ 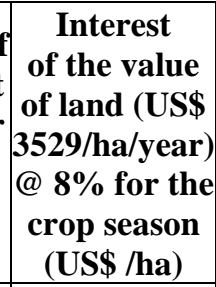 } & \multirow[b]{2}{*}{$\begin{array}{l}\text { Miscellaneous } \\
\text { cost @ 5\% of } \\
\text { the input cost } \\
\text { (US\$ /ha) }\end{array}$} & \\
\hline & Trees & $\begin{array}{l}\text { Cucumber } \\
\text { production }\end{array}$ & $\begin{array}{c}\text { Total } \\
\text { non- } \\
\text { material } \\
\text { cost }\end{array}$ & Seed & $\begin{array}{l}\text { Jute } \\
\text { rope }\end{array}$ & $\begin{array}{c}\text { Bamboo } \\
\text { stick }\end{array}$ & $\begin{array}{l}\text { Maintenance } \\
\text { cost of trees }\end{array}$ & $\begin{array}{c}\text { Initial } \\
\text { plantation } \\
\text { cost of } \\
\text { trees }\end{array}$ & $\mid \begin{array}{c}\text { Total } \\
\text { material } \\
\text { cost }\end{array}$ & & & & & \\
\hline $\mathrm{T}_{1}$ & $\cdots$ & 945.00 & 954.00 & 288.00 & 78.00 & 105.00 & $\ldots \ldots \ldots$ & $\ldots \ldots$ & 471.00 & 1425.00 & 114.00 & 282.00 & 71.00 & 1892.00 \\
\hline $\mathrm{T}_{2}$ & 168.00 & 945.00 & 1122.00 & 288.00 & 78.00 & 105.00 & 59.00 & 171.00 & 701.00 & 1823.00 & 146.00 & 282.00 & 91.00 & 2342.00 \\
\hline $\mathrm{T}_{3}$ & 169.00 & 945.00 & 1123.00 & 288.00 & 78.00 & 105.00 & 59.00 & 123.00 & 653.00 & 1776.00 & 142.00 & 282.00 & 89.00 & 2289.00 \\
\hline $\mathrm{T}_{4}$ & 171.00 & 945.00 & 1125.00 & 288.00 & 78.00 & 105.00 & 59.00 & 147.00 & 677.00 & 1802.00 & 144.00 & 282.00 & 90.00 & 2318.00 \\
\hline
\end{tabular}

